FLOOD OF APRIL 4-5, 1987, IN SOUTHEASTERN NEW YORK STATE, WITH FLOOD PROFILES OF SCHOHARIE CREEK

by Thomas J. Zembrzuskl, Jr. and Margaret L. Evans

U.S. GEOLOGICAL SURVEY

WATER-RESOURCES INVESTIGATIONS REPORT 89-4084

Prepared in cooperation with

NEW YORK STATE DEPARTMENT OF TRANSPORTATION

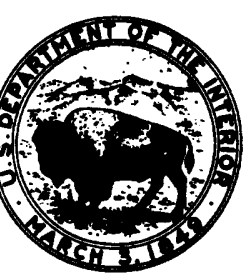

Albany, New York 
DEPARTMENT OF THE INTERIOR

MANUEL LUJAN, JR., Secretary

U.S. GEOLOGICAL SURVEY

Dallas L. Peck, Director

For additional information write to:

U.S. Geological Survey

Post office Box 1669

Albany, NY 12201
Copies of this report may be purchased from:

U.S. Geological Survey Books and Open-File Reports Eederal Center, Bldg. 810 Box 25425

Denver, CO 80225 


\section{CONTENTS}

Abstract. . . . . . . . . . . . . . . . . . . . . . 1

Introduction. . . . . . . . . . . . . . . . . . . . . 1

Purpose and scope. . . . . . . . . . . . . . . . . 3

Acknowledgments. . . . . . . . . . . . . . . . . 3

Physiography. . . . . . . . . . . . . . . . . . . . 8

Drainage basins. . . . . . . . . . . . . . . . 8

Principal streams. . . . . . . . . . . . . . . . 8

Schoharie Creek. . . . . . . . . . . . . . . . . 8

Catskill Creek . . . . . . . . . . . . . . . . . . 9

Esopus Creek. . . . . . . . . . . . . . . . . . 9

Rondout Creek. . . . . . . . . . . . . . . . . 9

Delaware River. . . . . . . . . . . . . . 10

Neversink River. . . . . . . . . . . . . . . 10

Climate . . . . . . . . . . . . . . . . . . . . . . . . 10

Storm and flood of April 4-5, 1987. . . . . . . . . . . . . . . . . . 11

Antecedent conditions. . . . . . . . . . . . . . . . . . 11

Precipitation. . . . . . . . . . . . . . . . . . 13

Flooding. . . . . . . . . . . . . . . . . . . . . . . 14

Flood discharge and frequency. . . . . . . . . . . . . 14

Description. . . . . . . . . . . . . . . . . . 19

Effect of reservoirs... . . . . . . . . . . 23

Schoharie Creek flood profiles. . . . . . . . . . . . . . 25

Summary . . . . . . . . . . . . . . . . . . . . 34

Selected references...................... . . . 34

\section{ILLUSTRATIONS}

Figure 1. Map showing major geographic features of southeastern

New York state. . . . . . . . . . . . . . . . . 2

2. Photographs showing:

A. Lost Clove Road bridge collapse over Esopus Creek

in Shandaken . . . . . . . . . . . . . . . . . . 4

B. Undermined Catskill Mountain Railroad track along

Esopus Creek in Phoenicia. . . . . . . . . . . . . . . . 4

C. Eroded County Route 22 along Catskill Creek in

Oak Hill. . . . . . . . . . . . . . . . . . . . 5

D. East Branch Delaware River overflow near Main

Street in Margaretville. . . . . . . . . . . . . . . . . 5

E. Inundated Route 30 along Schoharie Creek near

Middleburg . . . . . . . . . . . . . . . . . . . . . 6

F. Collapsed Mill Point Bridge (Route 161) over

Schoharie Creek. . . . . . . . . . . . . . . . . . . . . 6

G. Collapsed New York State Thruway bridge over

Schoharie Creek viewed from downstream and the air . . . 7 


\title{
FLOOD OF APRIL 4-5, 1987, IN SOUTHEASTERN NEW YORK STATE, WITH FLOOD PROFILES OF SCHOHARIE CREEK
}

\author{
by Thomas J. Zembrzuski, Jr. and Margaret L. Evans
}

\begin{abstract}
Intense rain that fell April 3-5, 1987, in southeastern New York state caused widespread flooding. As much as 9 inches of rain fell in watersheds of the Catskill Mountains, where the soils were already saturated, stream discharges were high, and some reservoirs were at or near capacity from snowmelt and previous rainfall. The flood along Schoharie Creek was the third largest since records began in the early 1900's and was exceeded only by the floods of October 1955 and March 1980. Peak discharge of many streams in the study area exceeded the 25-year recurrence interval. A New York State Thruway bridge collapsed into Schoharie Creek, killing 10 motorists. Flood damage to homes, businesses, crops, roadways, and bridges exceeded $\$ 65$ million. Five counties were declared as major disaster areas and eligible for Federal disaster assistance. This report presents a summary of peak stages and discharges at sites in the affected area, precipitation maps, floodflow hydrographs of seven streams, inflow hydrographs of six reservoirs, and flood profiles along 83 miles of Schoharie Creek from its mouth on the Mohawk River to its headwaters in the Catskill Mountains.
\end{abstract}

\section{INTRODUCTION}

An intense coastal storm that moved slowly over southeastern New York State on April 3-6, 1987, brought drenching rain that caused widespread flooding of streams draining the Catskill Mountains (fig. 1). In most areas, the flooding rivaled records set in March 1980, October 1955, and March 1951; in a few basins the floods were the most severe recorded in this century.

The rain began late on April 3. By April 6, when the storm ended, more than 9 in. (inches) of rain had fallen over the headwaters of the Schoharie, Esopus, Catskill, Rondout, Neversink, and East Branch Delaware basins.

Streams that were already high from rainfall and snowmelt from a week before rose quickly in response to the heavy rain. By late evening on April 4, when the rain began to slacken, the discharge of most rivers in the mountains had peaked, having reached flows near and above the 25 -year recurrence interval.

State and local emergency services evacuated more than 2,400 persons from their inundated homes. Rising water destroyed more than 50 homes and damaged almost 1,000 more. Many major and secondary highways and bridges were closed when floodwaters topped and washed out road surfaces or scoured and weakened highway embankments and bridge substructures. Floodwaters spread over thousands of acres of farmland, reportedly damaging more than 3,000 acres 


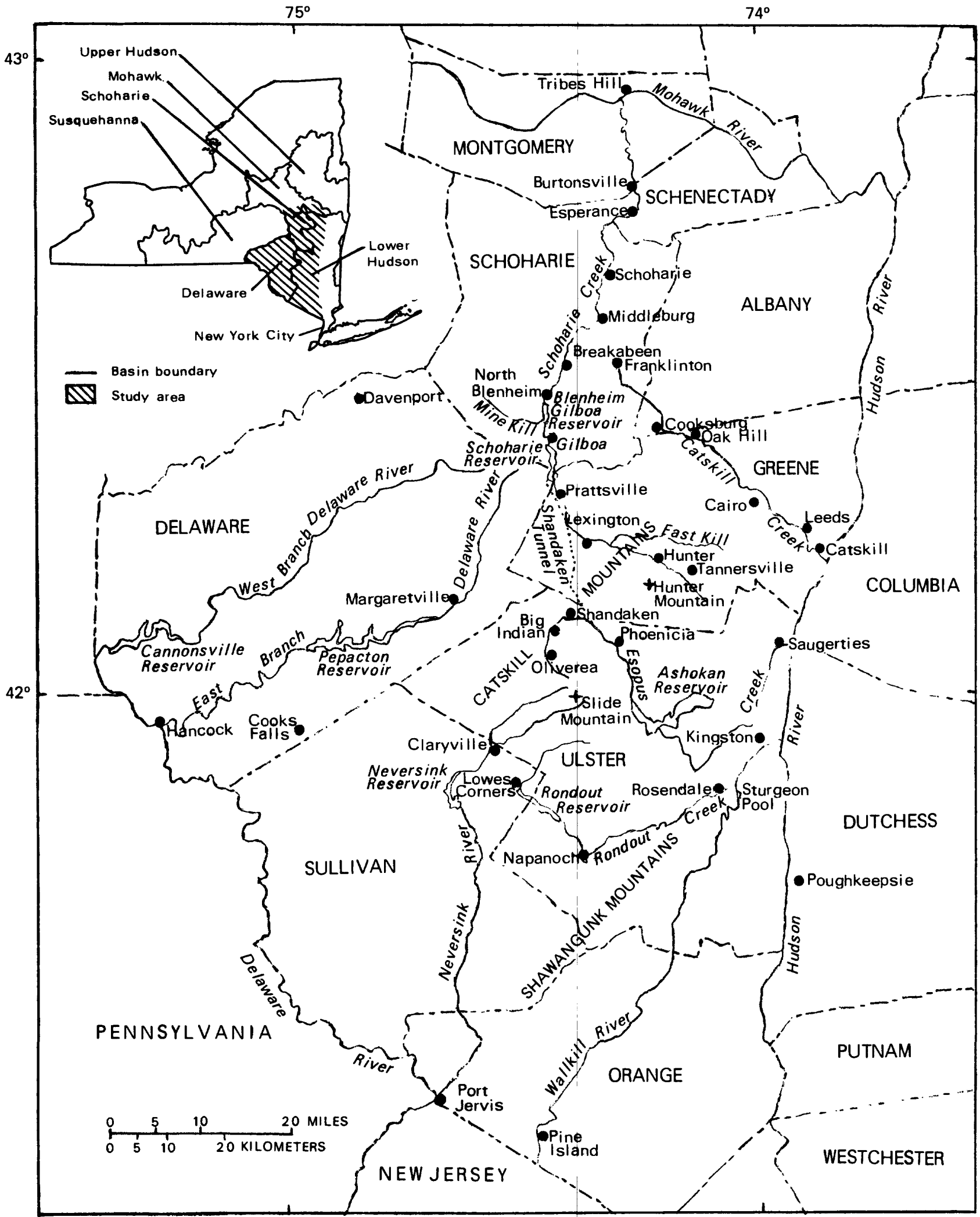

Base from U.S. Geological Survey

State base map. 1974

Figure 1.--Major geographic features of southeastern New York State. 
through erosion of topsoil and deposition of gravel and debris (figs. $2 \mathrm{~A}-2 \mathrm{G}$ ) . In all, homes, farms, businesses, roads, and bridges sustained direct damages in excess of $\$ 65$ million (A. Germano, New York State Emergency Management Office, written commun., 1987). The Governor declared five counties (Delaware, Greene, Montgomery, Schoharie, and Ulster) major disaster areas, and, on May 15, the President declared them eligible for Federal disaster assistance (New York State Disaster Preparedness Comm. written commun., 1987).

The devastation to mountain and valley communities was extensive, but the flood will be remembered most as the one that claimed 10 lives when the New York State Thruway (Interstate 90) bridge collapsed into Schoharie Creek (fig. 2G). During late morning on April 5, the 120-foot-long center span of the bridge fell into the flood-swollen creek. Five vehicles plummetted $80 \mathrm{ft}$ (feet) into the stream below. Search and rescue efforts were thwarted by deep water and swift currents. Investigators later blamed the failure on scour around one of the four piers that supported the bridge (National Transportation Safety Board, 1988).

\section{Purpose and Scope}

As part of a continuing program with the New York State Department of Transportation to document major floods in New York, the U.S. Geological Survey compiled and analyzed hydrologic data on the flood of April 4-5, 1987, in the Catskill Mountain region. This report documents the storm and flood in three tables and several graphs that present precipitation, discharge, and river-stage and reservoir level information. Water-surface profiles of Schoharie Creek that show water levels of the 1987 flood and the flood of record (October 1955) along $83 \mathrm{mi}$ (miles) above the mouth, are included.

\section{Acknowledgments}

Precipitation data were provided by the New York State Department of Environmental Conservation, Division of Air Resources, and the National Weather service. Data relating to flood damage were provided by the New York State Emergency Management office. Benchmark information for the flood profiles was tabulated by the New York State Department of Transportation. The New York Power Authority provided water-level and discharge data on Schoharie Creek. The New York City Department of Environmental Protection provided water-level, diversion, and discharge data on the reservoirs in the New York City water-supply system. Photographs were provided by Sidney Brown of the Schenectady Gazette, Schenectady; Fred McKinney of the Times Union, Albany; and Lee Ferris of the Mountain Eagle, Hunter, N.Y.

The authors acknowledge the efforts of the hydrologists and hydrologic technicians who collected the data for this report during and after the flood:
P. M. Burke
G. D. Casey
F. N. Dalton
D. D. Deloff
G. D. Firda
J. A. Gardner
G. J. Hebert
H. G. Lent
R. Lumia
R. J. Martin
P. S. Murdoch
J. A. Robideau
R. F. Snow
D. A. Stedfast

C. O. Szabo

F. S. Tooher

R. A. Trudell

L. A. Wagner

J. F. Wilson 


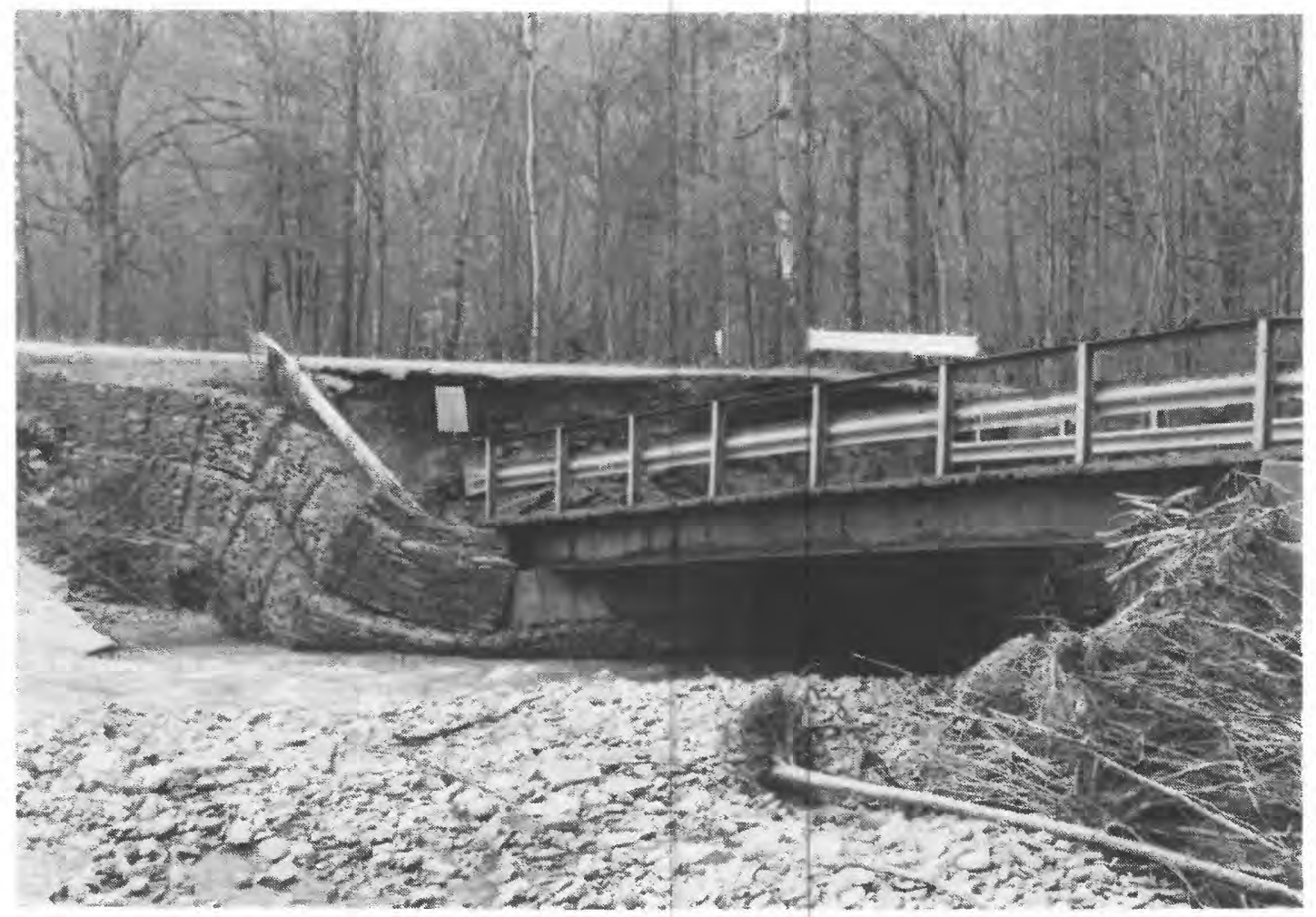

Figure 2A.--Lost Clove Road Bridge collapse over Esopus Creek in Shandaken, N.Y. (Courtesy of The Mountain Eagle)

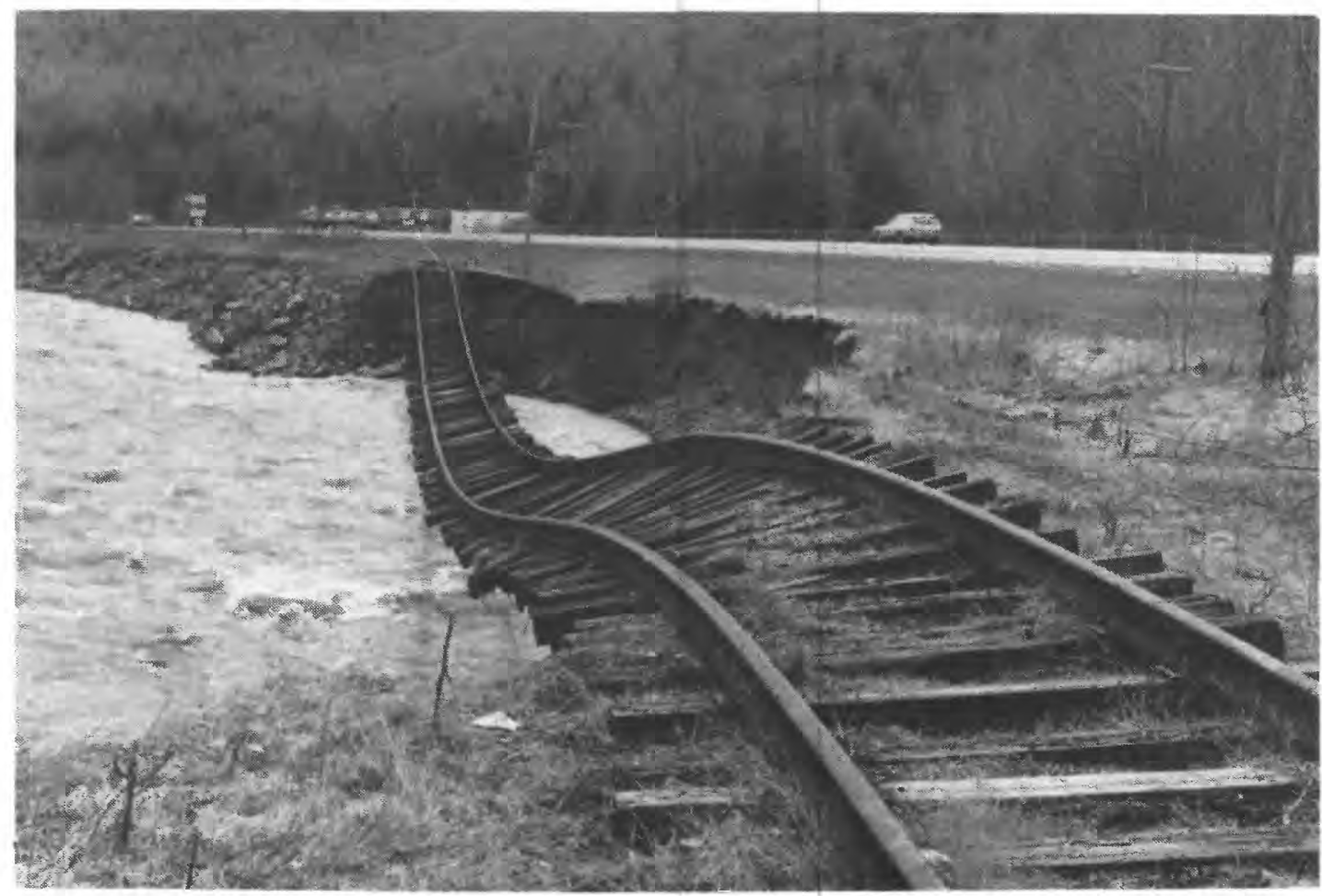

Figure 2B.--Undermined Catskill Mountain Railroad track along Esopus Creek in Phoenicia, N.Y. (Courtesy of the Mountain Eagle) 


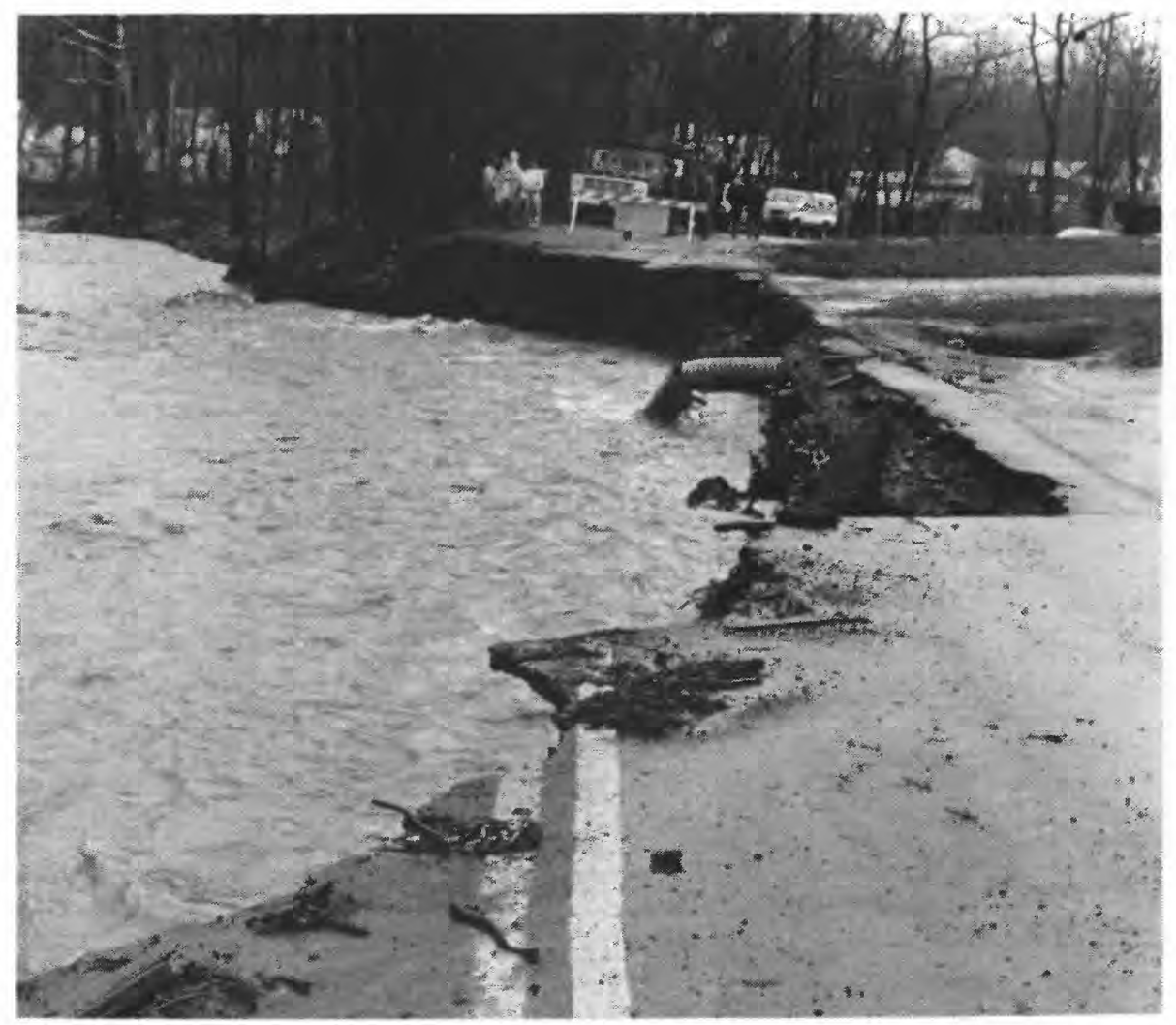

Figure 2C.--Eroded County Route 22 along Catskill Creek in Oak Hill, N.Y. (Courtesy of The Mountain Eagle)

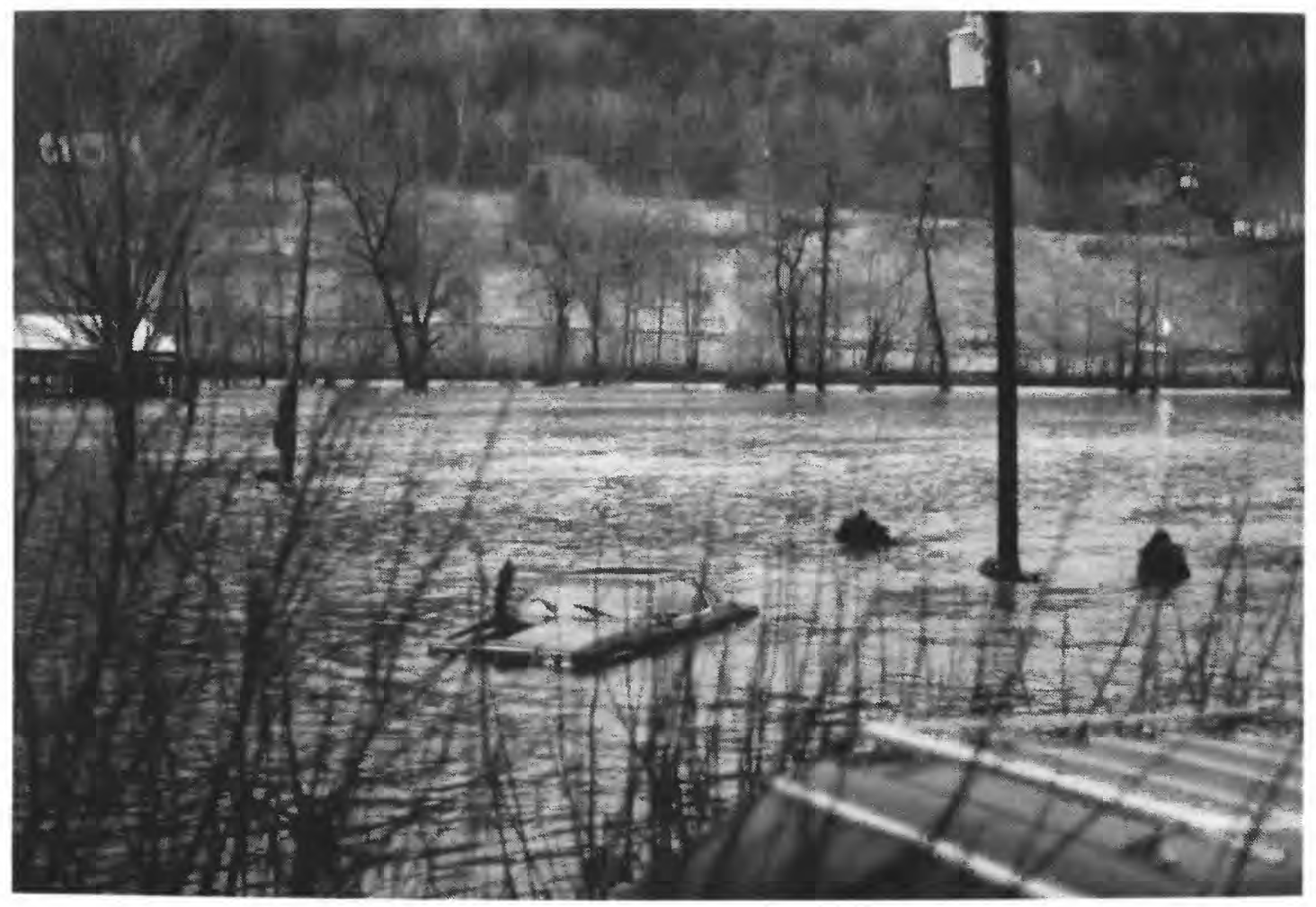

Figure 2D.--East Branch Delaware River overflow near Main Street in Margaretville, N.Y. (Courtesy of The Mountain Eagle) 


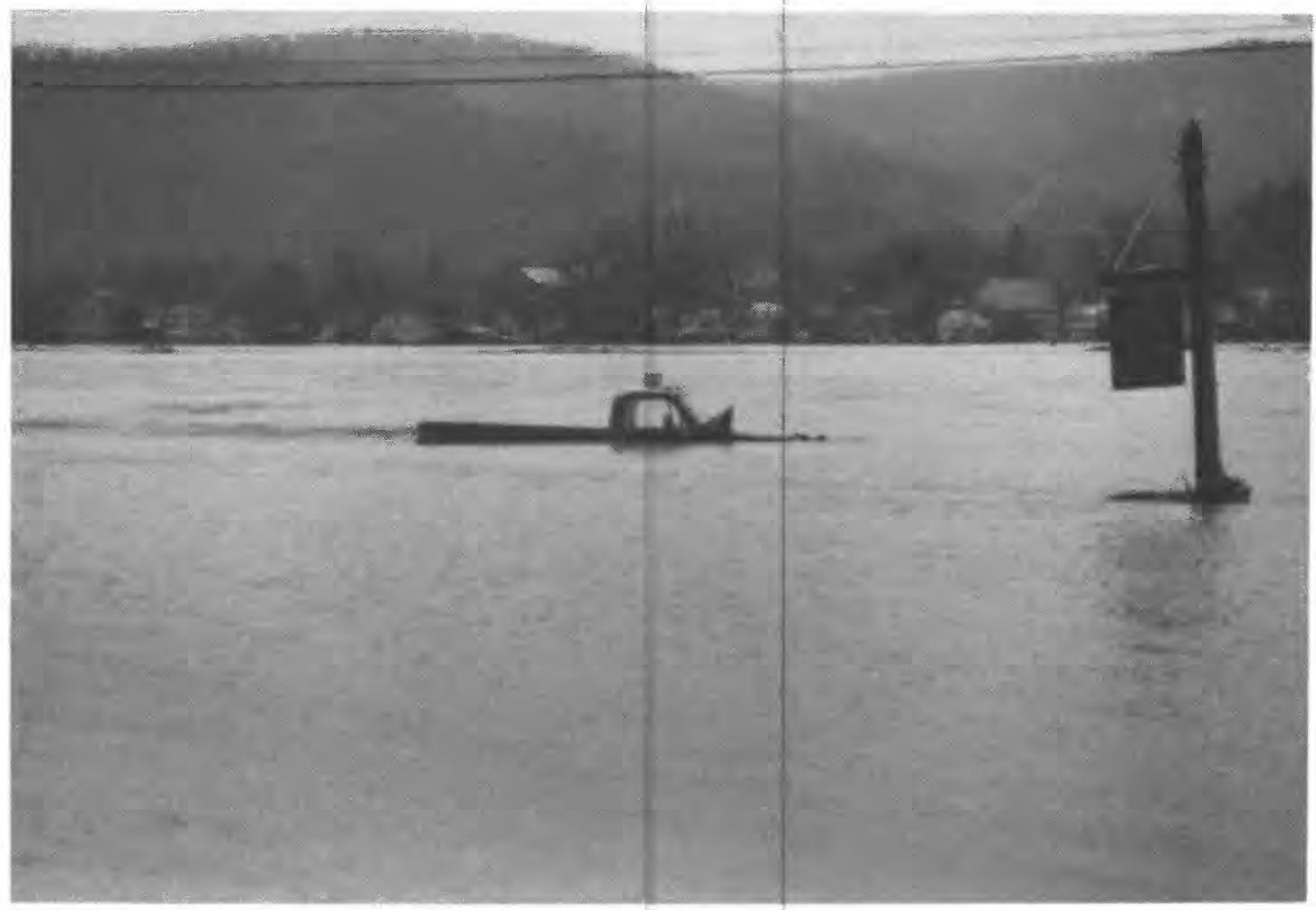

Figure 2E.--Inundated Route 30 along Schoharie Creek near Middleburg, N.Y. (Courtesy of the Mountain Eagle)

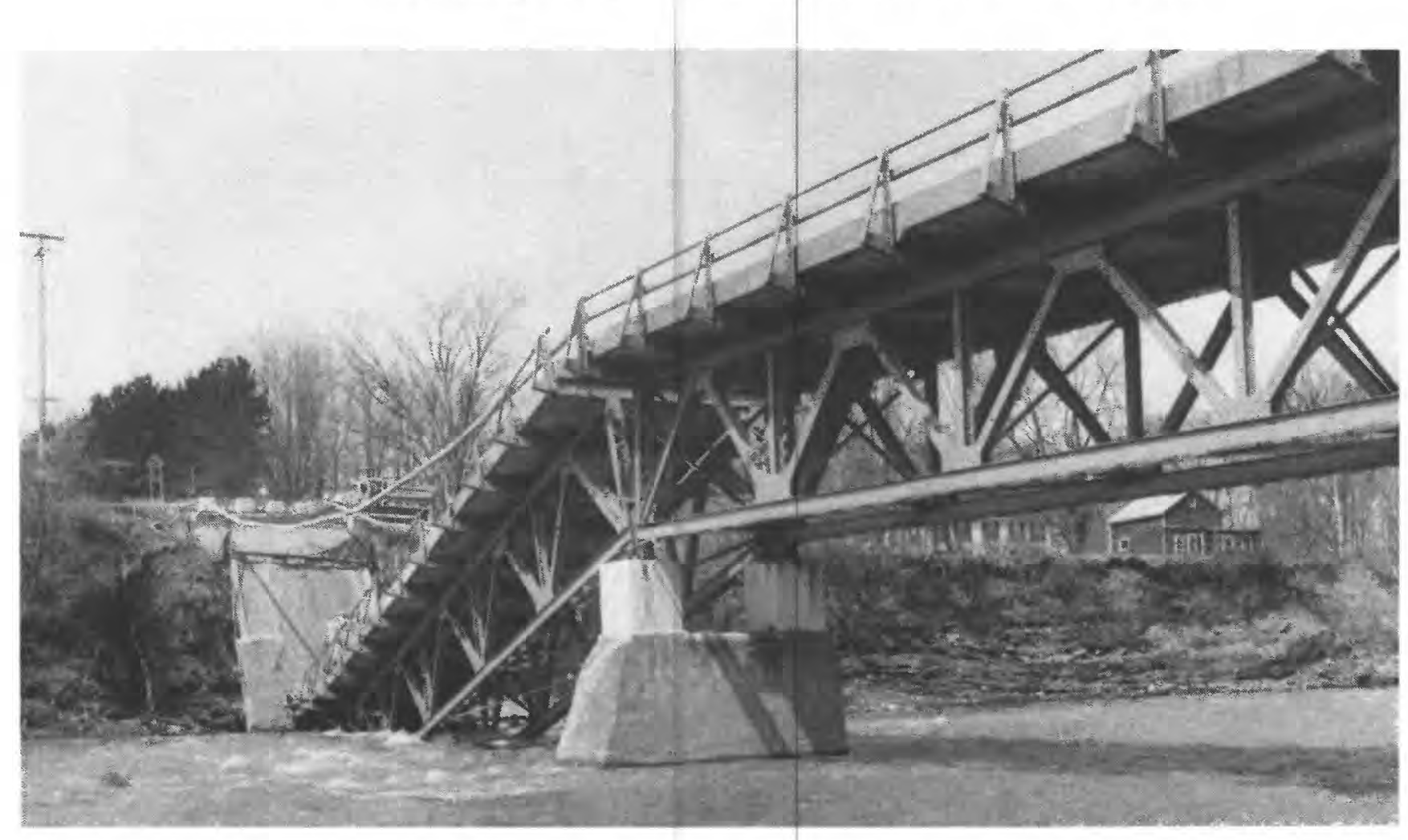

Figure 2F.--Collapsed Mill Point Bridge (Route 161) over Schoharie Creek. (Courtesy of the Times Union) 

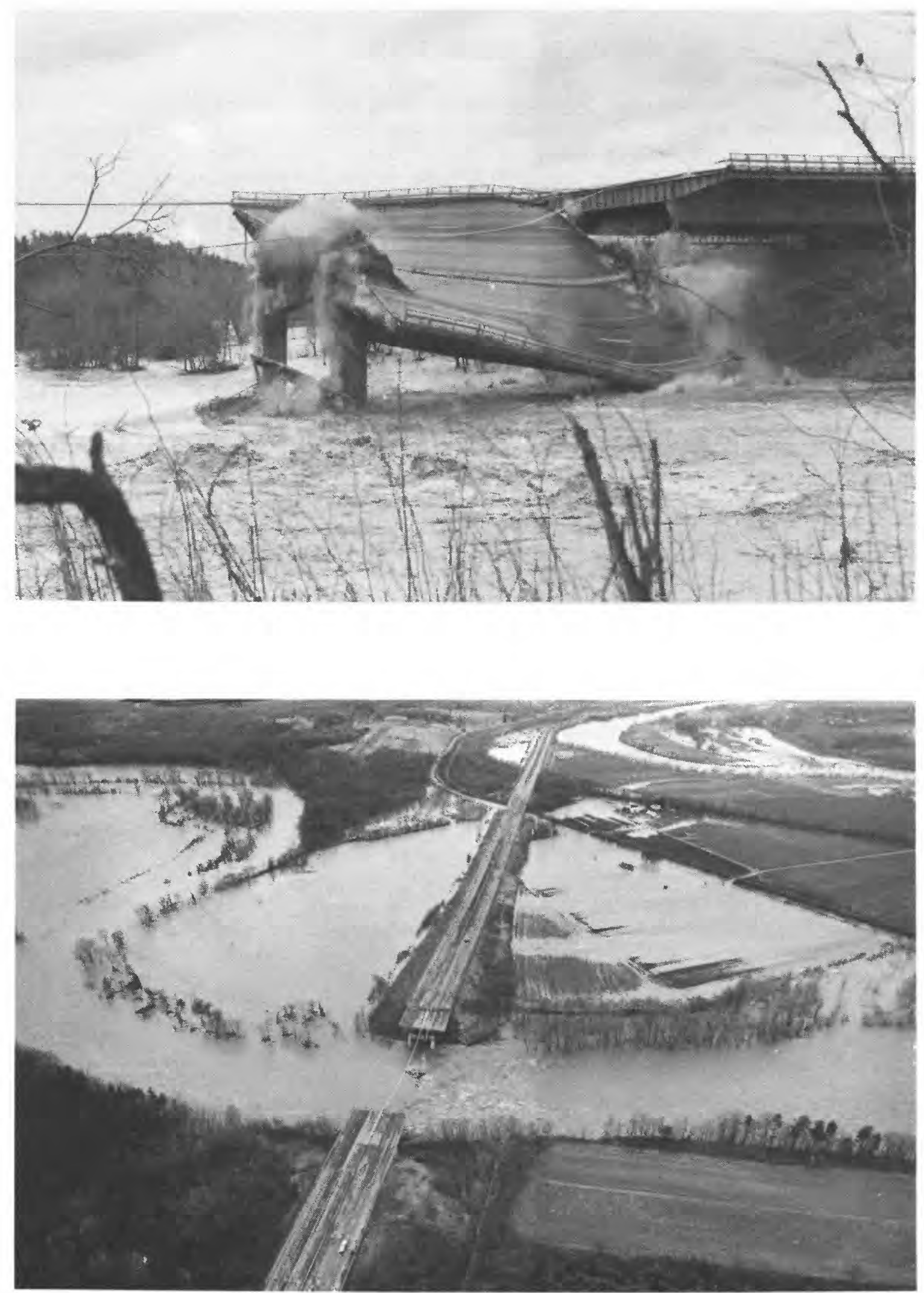

Figure 2G.--Collapsed New York State Thruway Bridge over Schoharie Creek. (Courtesy of Schenectady Gazette)

Above: as viewed from downstream. Below: aerial view. 


\section{PHYSIOGRAPHY}

The Catskill Mountains, in southeastern New York, consist primarily of Devonian-age sandstones and shales in massive beds underlain by Silurian shale, sandstone, and limestone. The area contains rugged mountains with narrow, steep-sided, V-shaped valleys. The mountain peaks range in elevation from 500 to 4,200 ft above sea level. Bedrock is exposed in many places, and elsewhere, the glacially derived soil is shallow and has little water-storage capacity but does support forest growth. South of the Catskills, the Shawangunk Mountains (fig. 1) are Silurian conglomerates overlain by soft ordovician shale. The Mohawk River valley to the north is a broad flood plain of Ordovician shale and limestone overlain by rich alluvial soil on the flats and sandy, gravelly loam on the higher areas (New England-New York InterAgency Committee, 1954).

\section{Drainage Basins}

The Catskill Mountains separate three major drainage basins: the Hudson, the Delaware, and the Susquehanna (fig. 1). The Hudson River originates in the Adirondack Mountains of New York and flows south for about $240 \mathrm{mi}$ or 315 river mi to the Atlantic Ocean at New York City. The upper Hudson basin drains 4,627 $\mathrm{mi}^{2}$ (square miles) from its headwaters to the confluence with the Mohawk River. The Mohawk River basin drains 3,462 $\mathrm{mi}^{2}$, and the lower Hudson River basin drains 4,561 $\mathrm{mi}^{2}$ from the mouth of the Mohawk River to the Atlantic ocean.

The Delaware River basin has its headwaters in the Catskill Mountains. The basin is $260 \mathrm{mi}$ long and drains a $12,765-\mathrm{mi}^{2}$ area, 2,362 $\mathrm{mi}^{2}$ of which are in New York State. This basin consists of the Upland, the Piedmont, and the Coastal plain sections, which drain 46, 31, and 23 percent of the basin, respectively. The upland section includes the New York part of the watershed and is characterized by a hilly, mountainous terrain with long, steep slopes (New England-New York Inter-Agency Committee, 1954).

The study area consists of the Schoharie basin, the southeastern part of the Mohawk basin, and the western half of the lower Hudson basin, all of which are within the Hudson River basin. It also includes the upland section of the Delaware River basin.

\section{Principal Streams}

Schoharie Creek is a major tributary to the Mohawk River, which is the largest tributary to the Hudson River. Catskill, Esopus, and Rondout Creeks drain directly into the Hudson River from the eastern slopes of the Catskills. The Neversink River drains into the Delaware River.

\section{Schoharie Creek}

Schoharie Creek has cut a deep valley from its headwaters high in the Catskills and drains part of the northern slopes of the mountains. It flows north for $83 \mathrm{mi}$ through wooded, mostly undeveloped land to become a major 
tributary (923- $\mathrm{mi}^{2}$ drainage area) to the Mohawk River. The Creek passes through Schoharie Reservoir and Blenheim-Gilboa Reservoir. Schoharie Reservoir, built in 1926, has a maximum capacity of 21,551 Mgal (million gallons). Schoharie Creek water is diverted out of the basin through Shandaken tunnel upstream from Gilboa Dam to Esopus Creek, where it is further routed to Ashokan Reservoir for New York City's water supply. Downstream from Schoharie Reservoir is Blenheim-Gilboa Reservoir, a pumped-storage

hydroelectric project. Water is pumped from this lower reservoir to the upper reservoir, from which it is released to generate power. Inflows from Schoharie Creek and the Mine Kill tributary are passed through the lower reservoir without modification.

\section{Catskill Creek}

Catskill Creek originates near the town of Franklinton at an elevation of $1,248 \mathrm{ft}$ above sea level. This $41.5-\mathrm{mi}$ creek, with a drainage area of 417 $\mathrm{mi}^{2}$, flows southeastward along the northern base of the Catskills to join the Hudson River at the village of Catskill. Between Franklinton and Cairo it is confined between steep, wooded slopes. From Cairo to leeds it meanders through an agricultural flood plain, then flows through a gorge as a series of pools, rapids, and falls before flowing onto the agricultural flood plain of the Hudson River (U.S. Army Corps of Engineers, 1975). The average slope of Catskill Creek is $30 \mathrm{ft} / \mathrm{mi}$ (feet per mile). The maximum slope of $52 \mathrm{ft} / \mathrm{mi}$ occurs in the reach from Franklinton to Cooksburg; the minimum slope of 15 $\mathrm{ft} / \mathrm{mi}$ is in the reach from Cairo to the Hudson River (New England-New York Inter-Agency Committee, 1954).

\section{Esopus Creek}

Esopus Creek starts near Oliverea in the Catskills and flows eastward for 45 miles to the Hudson River at Saugerties. Near Shandaken, Esopus Creek receives water diverted from Schoharie Reservoir through Shandaken Tunnel (fig. 1). Downstream from Phoenicia is Ashokan Reservoir, built in 1913. It has a usable storage of $127,858 \mathrm{Mgal}$ and was built to supply water to New York City. The creek's slope averages $30 \mathrm{ft} / \mathrm{mi}$ from Big Indian to Ashokan Reservoir and $22 \mathrm{ft} / \mathrm{mi}$ below the reservoir (New England-New York Inter-Agency Committee, 1954). Sixty percent of the 425- $\mathrm{mi}^{2}$ drainage area of Esopus Creek (Wagner, 1982) is above Ashokan Reservoir.

\section{Rondout Creek}

Rondout Creek and its tributary wallkill River have a total drainage area of $1,197 \mathrm{mi}^{2}$. Rondout Creek originates in the Shawangunk Mountains and flows eastward for $50 \mathrm{mi}$ (excluding Rondout Reservoir) to the Hudson River at Kingston. Rondout Reservoir, built in 1951, has a usable capacity of 50,048 Mgal (Firda and others, 1986). It is a holding reservoir for New York City and receives water from Neversink, Pepacton, and Cannonsville Reservoirs through a network of tunnels. The average slope of the creek is $16.5 \mathrm{ft} / \mathrm{mi}$, and the maximum slope is $270 \mathrm{ft} / \mathrm{mi}$ in the gorge at Napanoch. The downstream $4 \mathrm{mi}$ of Rondout Creek are tidal. 
The Wallkill River flows $90 \mathrm{mi}$ from northern New Jersey northeast to Rondout Creek downstream of Rosendale, only $7 \mathrm{mi}$ from its mouth in Kingston. Its drainage area is $786 \mathrm{mi}^{2}$. The Wallkill River basin near Pine Island is noted for its rich muck farmland, the "black dirt" used for onion growing. Orange county is one of the nation's leading onion-growing areas and produces 40 percent of New York's onion crop. The river valley has an average slope of $6 \mathrm{ft} / \mathrm{mi}$ with a maximum vertical fall of $107 \mathrm{ft}$ at Sturgeon Pool (New EnglandNew York Inter-Agency Committee, 1954).

\section{Delaware River}

The Delaware River basin has its headwaters on the western slopes of the Catskill Mountains. The river flows southwestward in two branches, the East and West, to Hancock, where they converge. The mainstem then flows southeastward, forming the New York-Pennsylvania border, then south past New Jersey and Delaware to the Atlantic Ocean.

The Delaware River basin in New York contains three reservoirs that supply water to New York City and serve to augment low flows of the Delaware River. Pepacton Reservoir, built in 1954 on the East Branch; Cannonsville Reservoir, built in 1963 on the West Branch, and Neversink Reservoir, built in 1953 on the Neversink River. The usable capacities of these reservoirs are as follows: Pepacton 140,190 Mgal, Cannonsville 95,706 Mgal, and Neversink $34,941 \mathrm{Mgal}$.

\section{Neversink River}

The Neversink River is a major tributary to the Delaware River with a drainage area of $346 \mathrm{mi}^{2}$. From its headwaters near slide Mountain it also flows southwestward in two branches to converge at claryville. Farther downstream it flows into Neversink Reservoir and, from the reservoir, flows southward to Port Jervis to join the Delaware River.

\section{CLIMATE}

Weather patterns in the study area are influenced by the mountain ranges and air movement through them. Prevailing winds in the Mohawk River watershed generally average 9 miles per hour from the west (U.S. Army Corps of Engineers, 1975). The northern part of the study area has cold, snowy winters with an average snowfall of $90 \mathrm{in.,}$ and short, mild summers. Farther south, the winters are milder and summers longer. Annual temperatures average $50^{\circ} \mathrm{F}$ (degrees Fahrenheit) but vary with latitude and altitude. Annual precipitation in the Catskills averages 45 in. Most summer precipitation is lost through evapotranspiration, but severe thunderstorms often cause flooding in the mountains. Runoff averages $20 \mathrm{in} / \mathrm{yr}$ (inches per year), more than half of which occurs from mid-February through mid-May. Spring runoff restores reservoir storage to anticipated seasonal demands. 


\section{STORM AND FLOOD OF APRIL 4-5, 1987}

\section{Antecedent Conditions}

The streams that drain the Catskill Mountains were extremely vulnerable to flooding before the storm that devastated the region on April 4 and 5 . Saturated soils, lack of reservoir storage (in some basins), and high water levels from snowmelt and a storm of a week before allowed streams to respond quickly to additional rainfall. An account of the weather and streamflow conditions during the preceding month is presented to explain the antecedent conditions.

March 1987 was drier and warmer than normal in the Catskill Mountains (Eggleston, 1987a). Most of the measurable rain fell in the first and last few days of the month. A storm in the first week that brought up to 2 in. of rain to the area caused moderate streamflow rises. Daily discharges of four representative Catskill Mountain streams for March and April 1987 are compared in figure 3 with the flows that are exceeded 80,50 , and 20 percent of the time. Cannonsville Reservoir, which had been full through the winter and had just recently (February 24) stopped discharging water over the Cannonsville Dam to the West Branch Delaware River, resumed spilling on March 3 (New York City Department of Environmental Protection, written commun., 1987).

Unseasonably warm weather on March 5-8 melted much of the snowpack. Snow depths on the ground, as measured by the National Weather Service observer at Slide Mountain (fig. 1), decreased from 28 in. on March 1 to 18 in. on March 9 (National Oceanic and Atmospheric Administration, 1987a). The snowmelt raised stream discharges higher than normal (fig. 3), but no serious flooding was reported. The water level of the Schoharie Reservoir had risen almost $0.3 \mathrm{ft}$ above the crest of the Gilboa Dam by March 10 .

A return to more seasonable weather began an unbroken recession of streamflow, supplemented by snowmelt, that lasted for the next 2 weeks. The water level of the Schoharie Reservoir briefly fell below the spillway elevation on March 18 and 19, and the discharge of some rivers had dipped below normal by March 21 (fig. 3). Showers on March 25-26 and, a few days later, on the 29th, along with daily high temperatures ranging from 50 to $60^{\circ} \mathrm{F}$, accelerated snowmelt again.

A low-pressure system associated with a cold front produced heavy rain over the Catskills on March 30 and 31 and showers on April 1. More than 3 in. fell over the headwaters of the Schoharie and Esopus basins, while generally less than 2 in. fell elsewhere (National Oceanic and Atmospheric Administration, 1987a). The rain melted the rest of the snow from all but the highest north-facing slopes and sheltered valleys (National Oceanic and Atmospheric Administration, 1987b). Streams rose to the mean annual flood range throughout the region, and storage in the Pepacton, Neversink, Ashokan, and Rondout Reservoirs increased markedly. The Schoharie and Cannonsville Reservoirs continued to spill. 
EAST BRANCH DELAWARE RIVER AT MARGARETVILLE

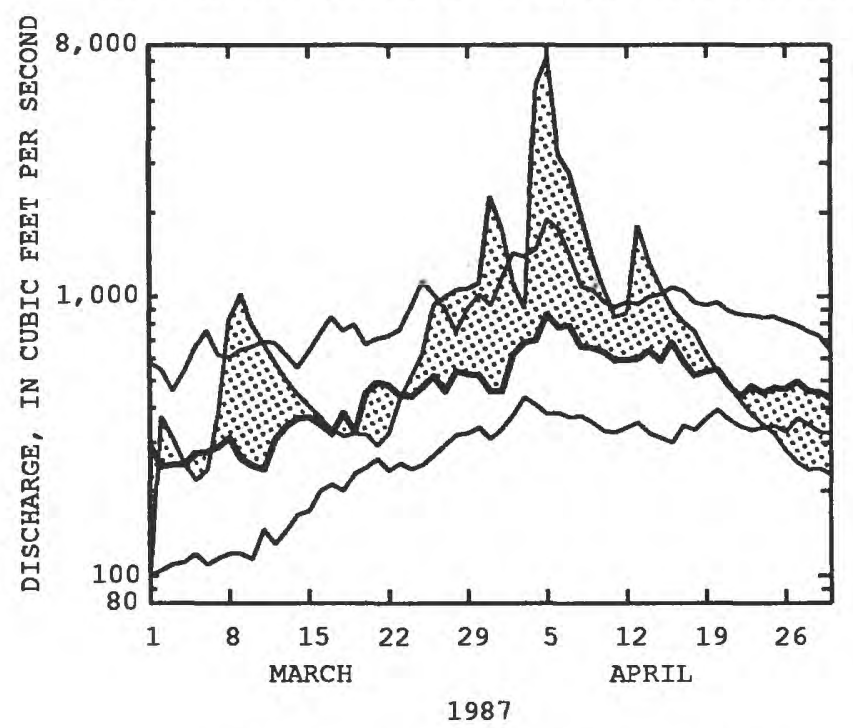

ESOPUS CREEK AT COLDBROOK

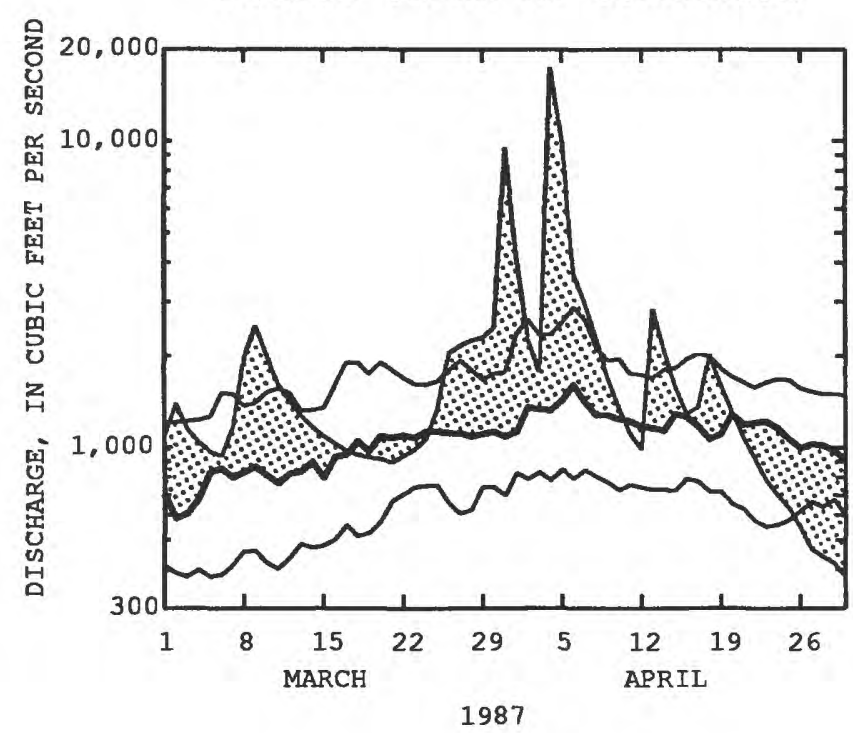

EXPLANATION

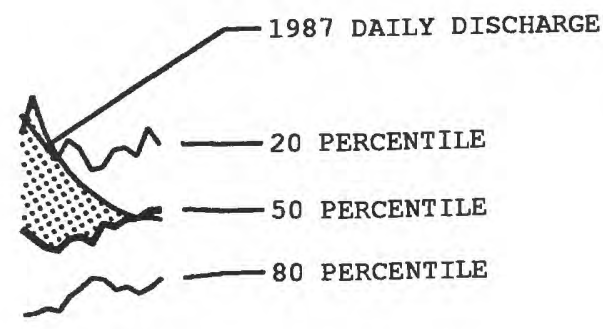

SCHOHARIE CREEK AT PRATTSVILLE

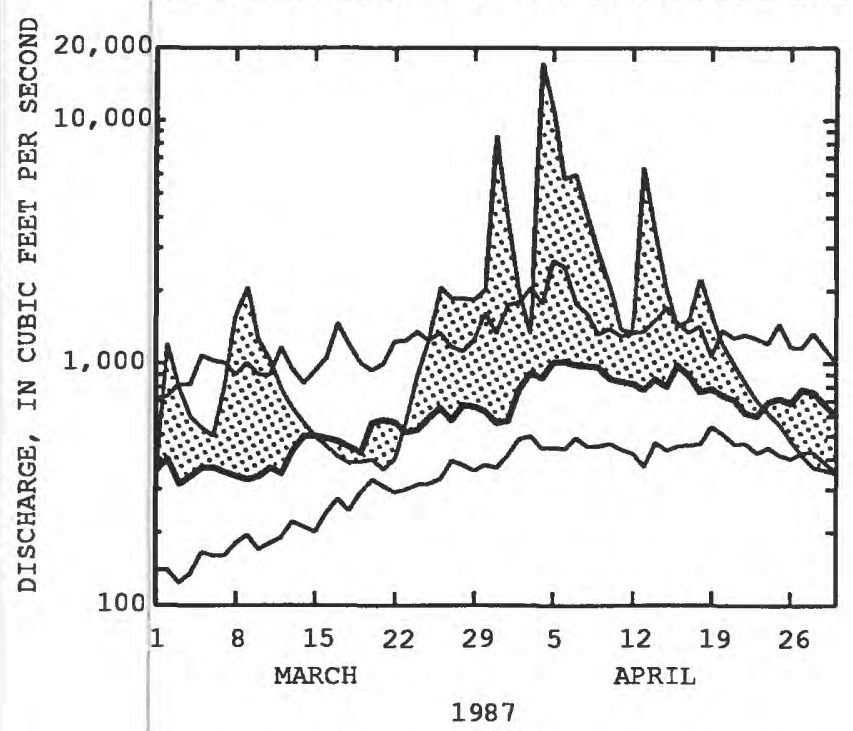

NEVERSINK RIVER NEAR CLARYVILLE

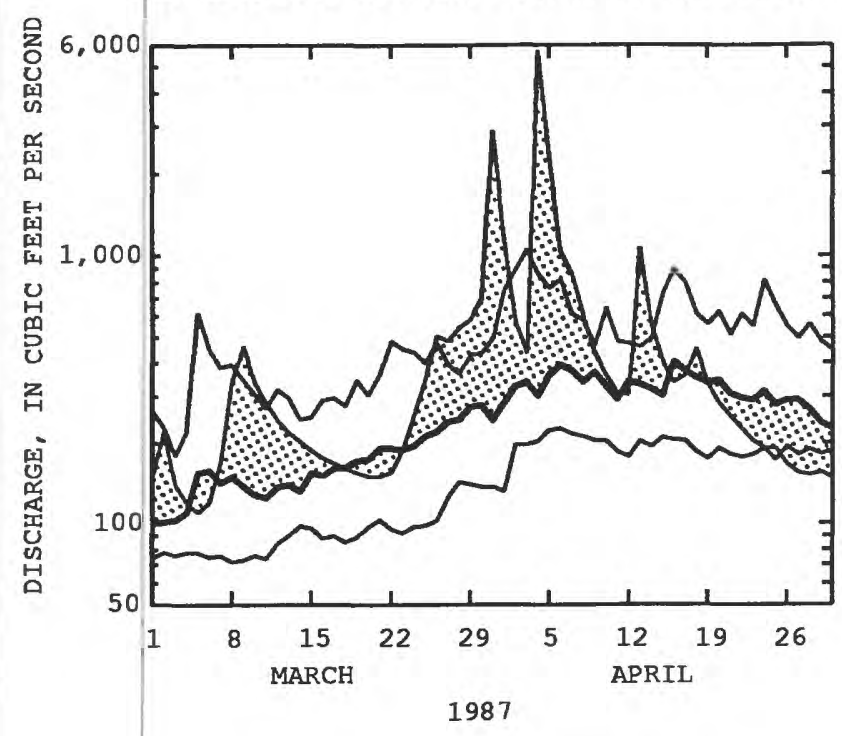

Figure 3.

Daily discharges for March and April 1987 in relation to flows exceeded 80,50 , and 20 percent of the time on fpur Catskill Mountain streams. (Locations are shown in fig. 1). 


\section{Precipitation}

The storm that caused the floods of April 4 and 5 began in the southeastern United States as a low-pressure disturbance along a north-southoriented front. The front had passed through New York and stalled over New England on April 2 (Eggleston, 1987b). The low-pressure system moved slowly northward up the coast along the front, spreading showers over the Catskills on April 2. Fed by moisture from the Atlantic Ocean, the storm began to strengthen on the afternoon of April 3 and was producing steady rain over all of southeastern New York by the next morning. The heaviest drenching occurred between 1200 and 1800 hours on April 4. During that evening and through the next day, intermittent downpours continued. By April 6, most of the rain was over, but atmospheric instability continued until the storm moved out to sea on April 8.

The intensity of the storm at selected recording precipitation gages is illustrated in figure 4. Comparison of these graphs indicates the timing of the most intense rainfall on April 4 from the southeastern to the northwestern part of the region. Regardless of the total amount, the heaviest rain fell during the morning and afternoon in the south and east; the rain in the north and west was not only lighter, but the heaviest period was delayed until later in the day.

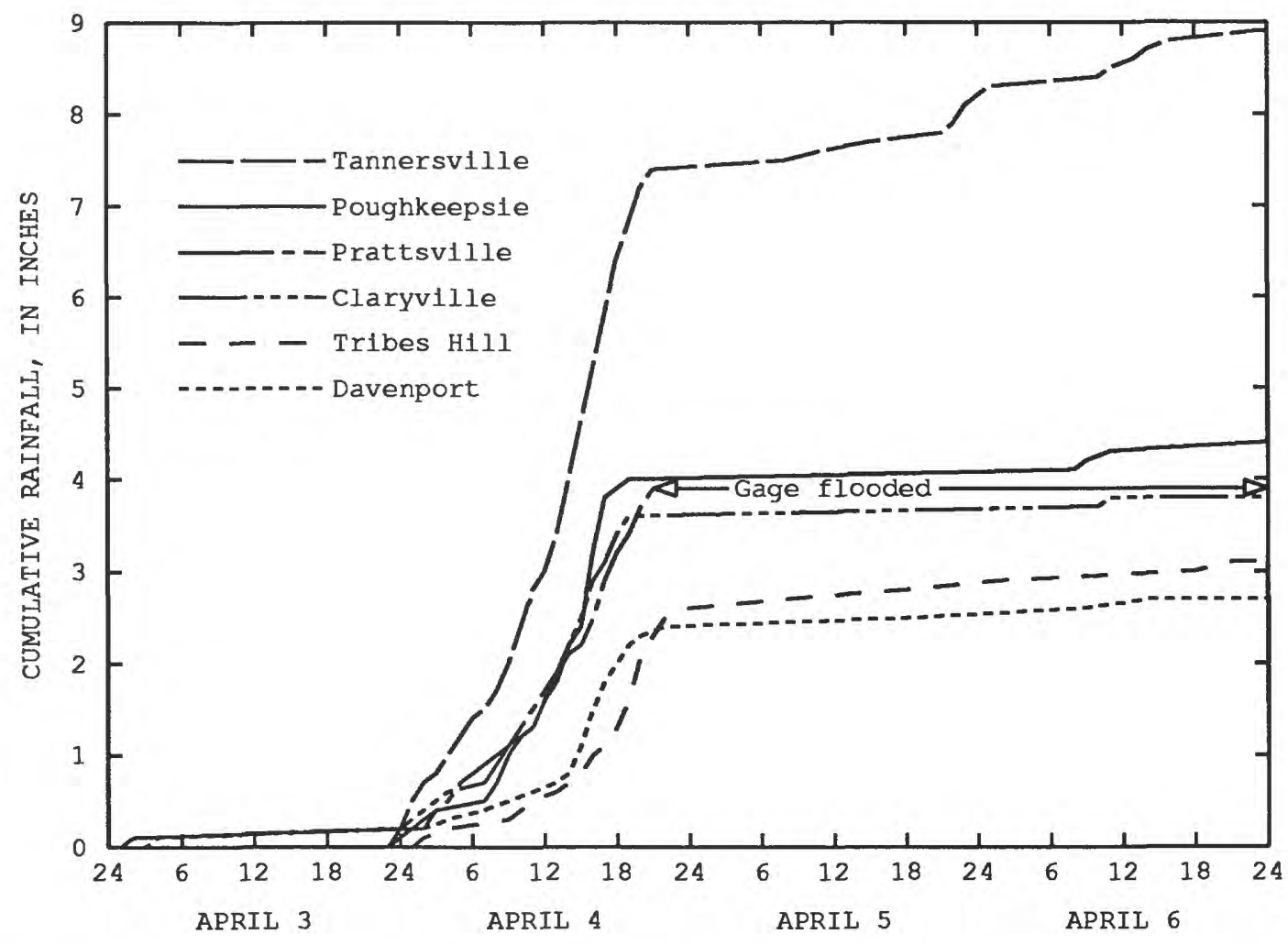

Figure 4.--Cumulative rainfall at six selected stations, April 3-6, 1987. (Locations are shown in fig. 1.) 
Topographic and meteorological factors influenced the local variations in storm intensity. Spatial variability is influenced by the Catskill landscape, as shown by the 100-year, 24-hour-duration contours in figure 5A. The maximum rain recorded during the 24-hour period that ended at 0700 hours on April 5 exceeded 6 in. (National Oceanic and Atmospheric Administration, 1987c) (fig. $5 \mathrm{~A})$ and was centered around the highest peaks in the Catskills, slide Mountain $(4,204 \mathrm{ft})$ and Hunter Mountain $(4,025 \mathrm{ft})$. Prevailing winds from the east and southeast and orographic effects of the Catskills combined to generate the greatest rainfall totals on the eastern slopes of the mountains. The same general precipitation pattern held for the 48-hour period ending at 0700 hours on April 5 (fig. 5B) and for the 4-day (April 3-6) total storm rainfall (fig. 5C). The maximum rainfall recorded for the 4-day period was 9.09 in., at slide Mountain. The total at Tannersville, approximately $8 \mathrm{mi}$ west-northwest of Hunter Mountain, was 8.0 in. for the same period. Rainfall-frequency relations and station totals are given for selected durations and precipitation stations in table 1 (p. 18) (U.S. Department of Commerce, 1961).

\section{Flooding}

Ten lives were lost when floodwaters collapsed a 120-ft span of the New York State Thruway bridge over Schoharie Creek. Damage to the bridge was estimated at $\$ 32.5$ million, and the loss of continuity of this major east-west roadway imposed a severe burden on other state and local roads and bridges not designed for heavy traffic. Flood damages to other major and secondary highways and bridges, in the form of washouts, undermining, debris deposition and blockage, and road-surface and substructure damage, disrupted traffic, especially for local government emergency services. These damages were estimated at $\$ 25.1$ million.

Nearly 2,400 people were evacuated from homes and businesses. Twentyfour shelters were set up to house and feed 460 people. Approximately 50 single-family homes were destroyed or condemned, and another 982 residences were damaged as a result of flooding. Private residential damages were estimated at $\$ 3.1$ million. Agricultural properties lost an estimated $\$ 2.6$ million worth in flooded farmland and crops.

The Thruway bridge collapse was blamed for economic losses to businesses in Montgomery County, and the flooding caused economic losses in other counties in the study area. More than 90 businesses were damaged to varying degrees; total loss was estimated at $\$ 2.2$ million.

\section{Flood Discharge and Frequency}

Data for the flood of April 4-5, 1987 at 73 sites on streams in or adjacent to the Catskill region are presented in table 3 (at end of report). Locations of these sites are shown in figure 10 (p. 43). Gage height, discharge, time of peak, recurrence interval, and historic flood data are given, as appropriate, for 48 continuous-record stations, 10 crest-stage stations, 5 discontinued stations, and 10 miscellaneous-measurement sites. Active gaging stations record stream stage continuously (or at preselected time intervals), whereas crest-stage stations record only the peak stage between inspections at the gage. Indirect measurements of discharge were made after the flooding at discontinued stations and miscellaneous-measurement sites. 


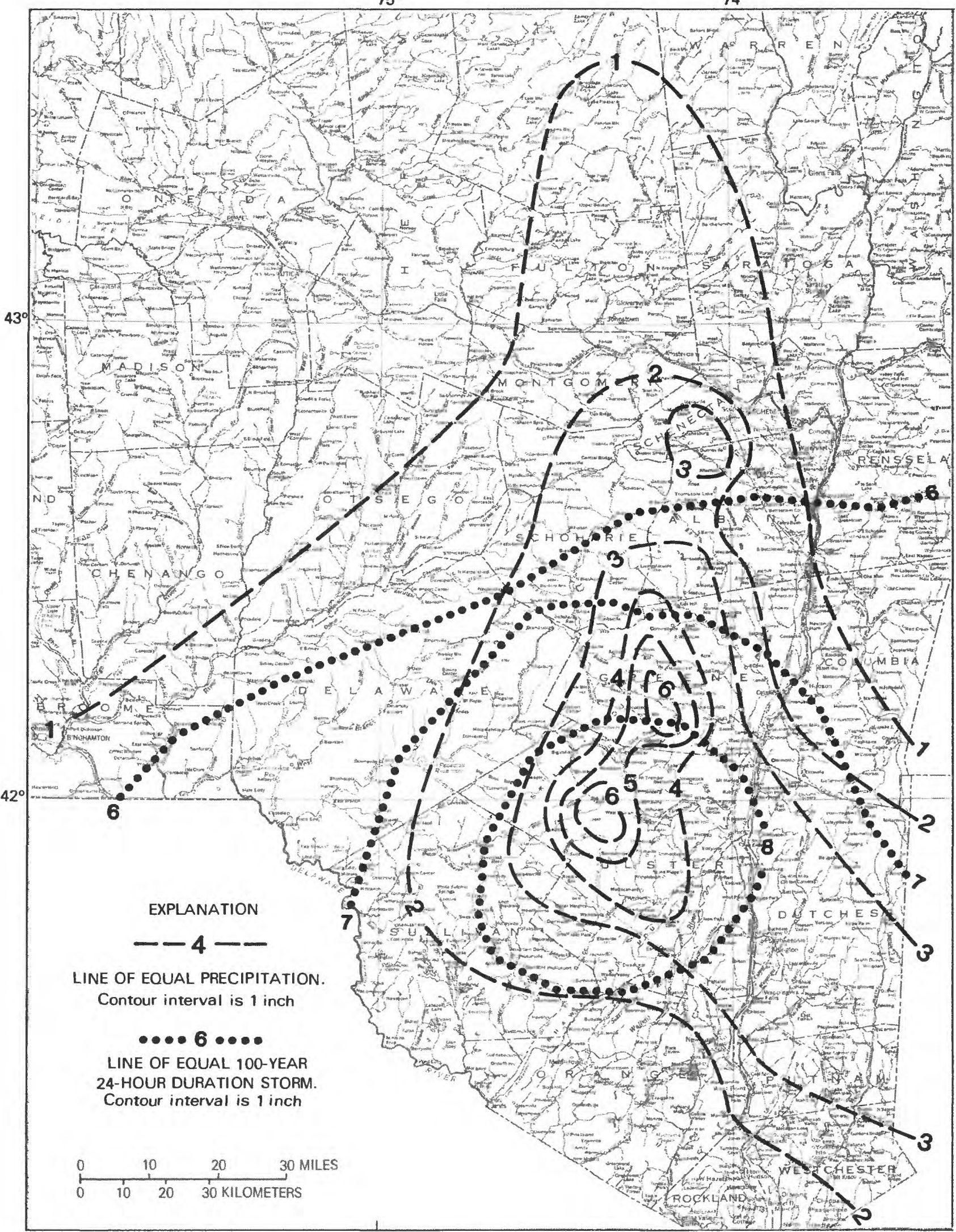

Base from U.S. Geological Survey

State base map, 1,500,000, 1974

Figure 5A.--Precipitation for the April 1987 storm after 24 hours (ending April 5 at 0700 hours) and for 100-year 24-hour duration storm. 


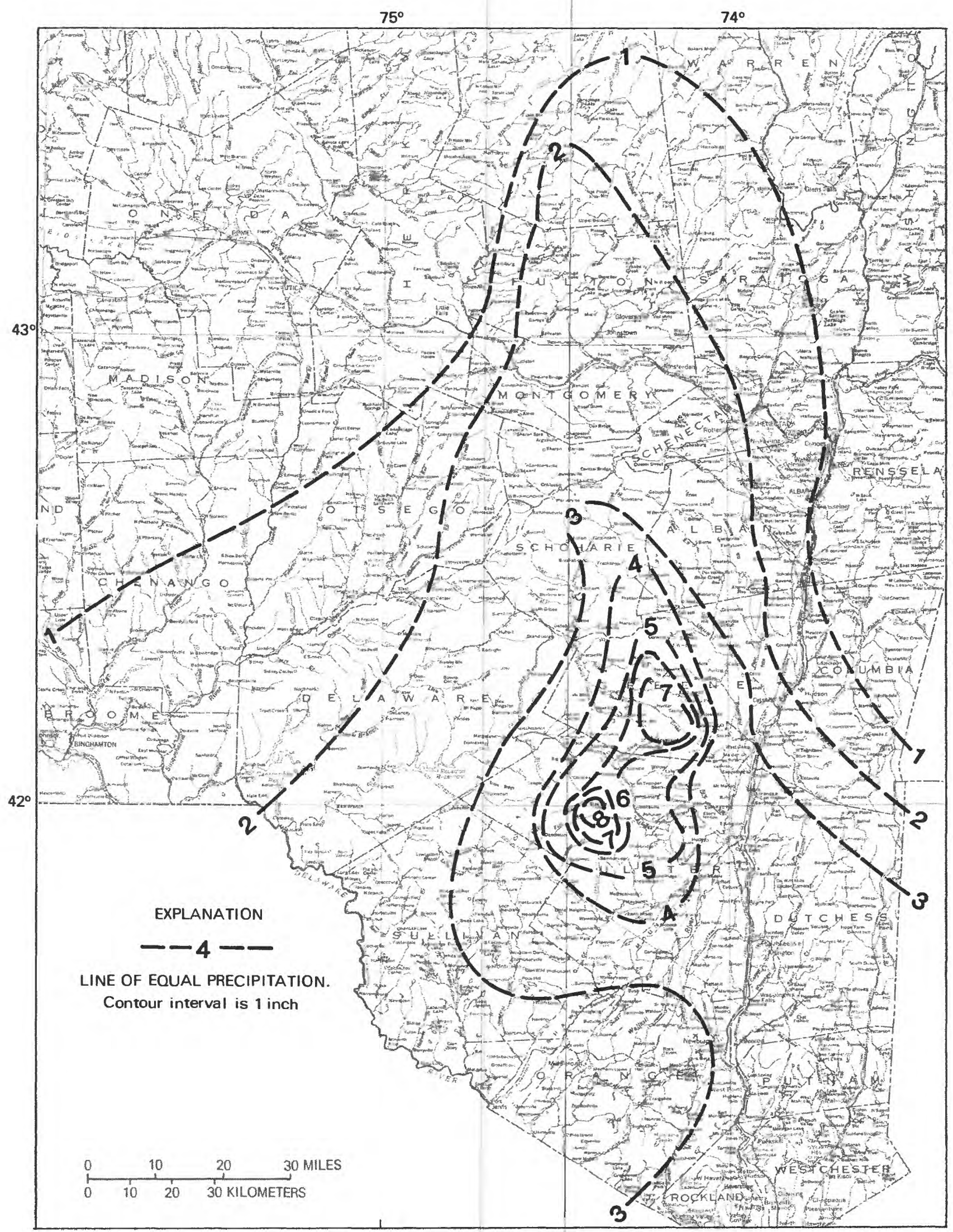

Base from U.S. Geological Survey

State base map, 1:500,000, 1974

Figure 5B.--Precipitation for the April 1987 storm after 48 hours (ending April 5 at 0700 hours). 


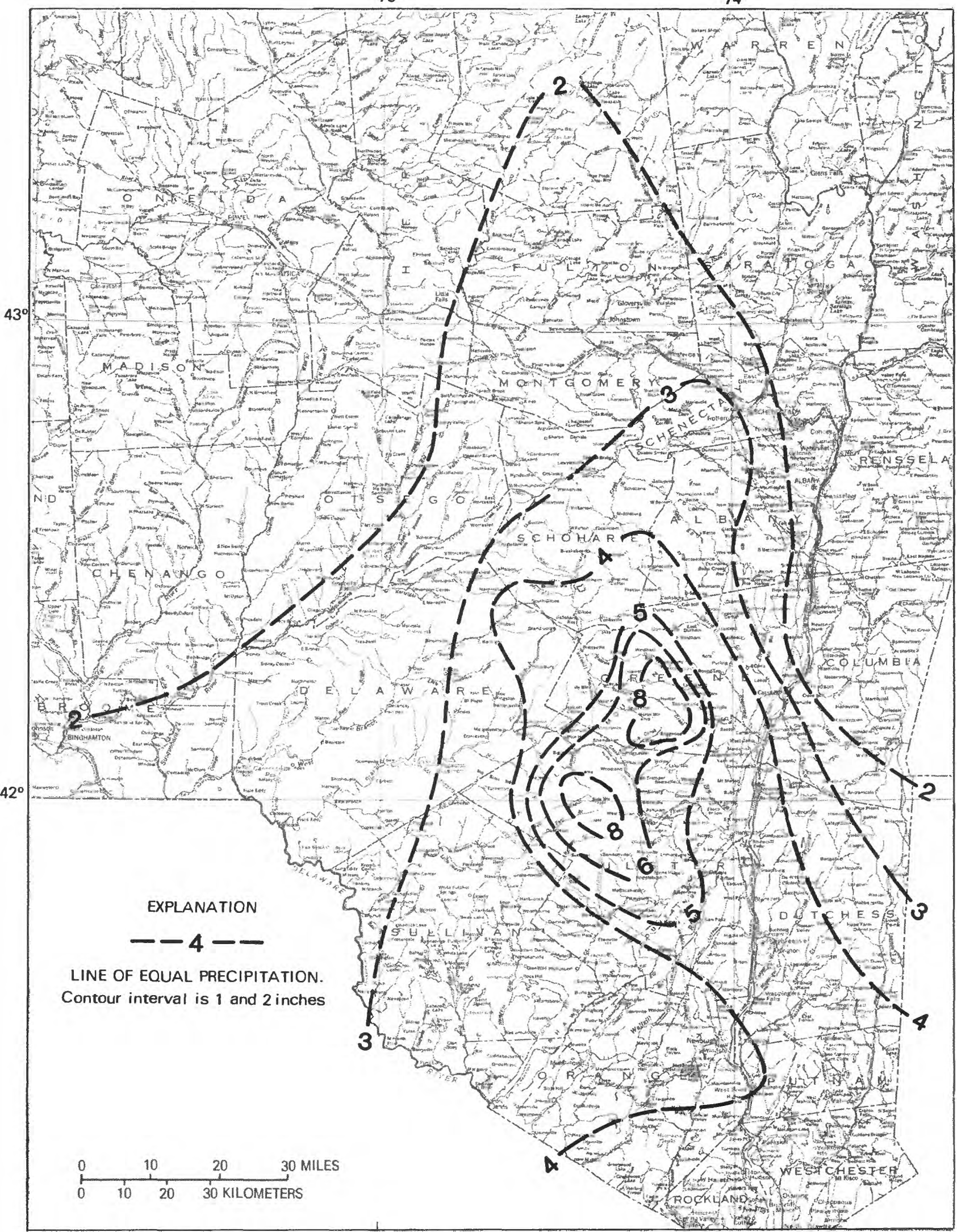

Base from U.S. Geological Survey

State base map, 1:500,000,1974

Figure 5C.--Precipitation for the April 1987 total storm rainfall after 96 hours (April 3-6). 
Table 1.--Rainfall-frequency relations for selected storm durations and April 1987 storm at selected precipitation stations in southeastern New York.

[Data from U.S. Department of Commerce, Weather Bureau, 1961; National Oceanic and Atmospheric Administration, 1987a, 1987b, and written commun., 1987. Locations are shown in fig 1.]

\begin{tabular}{|c|c|c|c|c|c|c|c|}
\hline \multirow{2}{*}{$\begin{array}{l}\text { Recurrence } \\
\text { Interval } \\
\text { (years) }\end{array}$} & \multicolumn{7}{|c|}{ Station name } \\
\hline & $\begin{array}{l}\text { Pough- } \\
\text { keepsie }\end{array}$ & $\begin{array}{l}\text { Tanners- } \\
\text { ville }\end{array}$ & $\begin{array}{l}\text { Slide } \\
\text { Mountain }\end{array}$ & $\begin{array}{l}\text { Clary- } \\
\text { ville }\end{array}$ & $\begin{array}{l}\text { Pratts- } \\
\text { ville }\end{array}$ & $\begin{array}{l}\text { Daven- } \\
\text { pert }\end{array}$ & $\begin{array}{l}\text { Tribes } \\
\text { Hill }\end{array}$ \\
\hline & \multicolumn{7}{|c|}{ Depth for 6 -hour rainfall, in inches } \\
\hline 2 & 2.5 & 2.5 & 2.7 & 2.6 & 2.5 & 2.0 & 2.0 \\
\hline 5 & 3.3 & 3.0 & 3.6 & 3.5 & 3.0 & 2.5 & 2.4 \\
\hline 10 & 3.6 & 3.5 & 4.1 & 4.0 & 3.5 & 3.0 & 2.9 \\
\hline 25 & 4.5 & 4.1 & 4.6 & 4.5 & 3.9 & 3.7 & 3.5 \\
\hline 50 & 4.9 & 4.8 & 5.2 & 5.0 & 4.4 & 3.9 & 3.8 \\
\hline 100 & 5.1 & 5.0 & 5.8 & 5.6 & 5.0 & 4.4 & 4.0 \\
\hline \multicolumn{8}{|l|}{$\overline{\text { April storm }}$} \\
\hline \multirow[t]{2}{*}{ total } & 2.5 & 3.4 & a & 1.8 & 1.7 & 1.5 & 1.4 \\
\hline & \multicolumn{7}{|c|}{ Depth for 12-hour rainfall, in inches } \\
\hline 2 & 3.0 & 3.0 & 3.6 & 3.5 & 2.9 & 2.5 & 2.4 \\
\hline 5 & 4.0 & 3.5 & 4.2 & 4.1 & 3.6 & 3.0 & 2.9 \\
\hline 10 & 4.6 & 4.5 & 5.0 & 4.9 & 4.2 & 3.7 & 3.4 \\
\hline 25 & 5.3 & 5.0 & 5.6 & 5.0 & 4.8 & 4.0 & 3.9 \\
\hline 50 & 6.0 & 5.5 & 6.2 & 6.0 & 5.2 & 4.6 & 4.2 \\
\hline 100 & 6.7 & 6.2 & 7.2 & 7.0 & 6.0 & 5.2 & 4.9 \\
\hline \multicolumn{8}{|l|}{ April storm } \\
\hline total & 3.5 & 5.5 & a & 2.9 & $2.8 b$ & 1.8 & 2.1 \\
\hline & \multicolumn{7}{|c|}{ Depth for 24-hour rainfal1, in inches } \\
\hline 2 & 3.5 & 3.3 & 4.1 & 4.0 & 3.1 & 2.9 & 2.7 \\
\hline 5 & 5.0 & 4.6 & 5.3 & 5.0 & 4.4 & 3.5 & 3.4 \\
\hline 10 & 5.5 & 5.1 & 6.2 & 6.0 & 5.0 & 4.3 & 3.9 \\
\hline 25 & 6.2 & 6.1 & 6.7 & 6.5 & 6.0 & 4.9 & 4.7 \\
\hline 50 & 7.0 & 7.0 & 7.5 & 7.2 & 6.8 & 5.5 & 4.9 \\
\hline 100 & 7.8 & 7.5 & 8.3 & 8.1 & 7.3 & 5.9 & 5.5 \\
\hline \multicolumn{8}{|l|}{$\overline{\text { April storm }}$} \\
\hline \multirow[t]{2}{*}{ total. } & 4.0 & 7.3 & $6.64 a, c$ & 3.6 & $3.8 b$ & 2.4 & 2.6 \\
\hline & \multicolumn{7}{|c|}{ Depth for 48-hour rainfall, in inches } \\
\hline 2 & 4.5 & 4.0 & 4.7 & 4.5 & 3.7 & 3.4 & 3.1 \\
\hline 5 & 5.6 & 5.2 & 6.0 & 5.9 & 5.0 & 4.3 & 3.9 \\
\hline 10 & 6.6 & 6.1 & 7.0 & 6.8 & 5.7 & 4.8 & 4.6 \\
\hline 25 & 7.8 & 7.2 & 8.4 & 8.1 & 7.0 & 5.9 & 5.3 \\
\hline 50 & 8.6 & 8.0 & 9.2 & 9.0 & 7.7 & 6.4 & 5.9 \\
\hline 100 & 9.7 & 9.0 & 10.3 & 10.1 & 8.8 & 7.0 & 6.6 \\
\hline April storm & & & & & & & \\
\hline total & 4.0 & 8.0 & $8.54 \mathrm{a}, \mathrm{s}$ & 3.6 & $3.9 b$ & 2.4 & 2.8 \\
\hline
\end{tabular}

a Daily precipitation station.

b Gage flooded at $2200 \mathrm{hr}$ April 4. Indicated duration total may have been higher.

c Gage read daily at $0700 \mathrm{hr}$. Maximum rainfall for indicated duration probably was higher. 
Data in table 3 are grouped by the major river basin in which the site is located. The sites are listed by U.S. Geological survey station number (downstream order). The period-of-record column represents only those water years in which peak stage or discharge data were obtained. Not all periods listed are continuous or complete; an occasional year or two of peak-flow record may be missing. The previous-flood-of-record column may contain two entries; the first includes the previous maximum known discharge and associated gage height, and the second gives the previous maximum known gage height if it exceeds that in the first entry. Discharge is given in cubic feet per second $\left(\mathrm{ft}^{3} / \mathrm{s}\right)$ and in cubic feet per second per square mile $\left[\left(\mathrm{ft}^{3} / \mathrm{s}\right) / \mathrm{mi}^{2}\right]$. Unless noted otherwise, all stages were obtained from the gage record.

Frequency analysis of the gaging-station flood records provides a means of estimating the probability of occurrence of a given discharge. Flood frequency is commonly expressed in terms of "recurrence interval" or "probability of being exceeded." One is the reciprocal of the other. The 100year flood, for example, has a probability of 0.01 (1-percent chance) of being equaled or exceeded in any given year. These statistics reflect long-term averages, thus, rare (large-magnitude) floods can recur at short intervals, or even within the same year.

Data from sites at which systematic annual flood data have been collected were fitted to a log-Pearson Type III distribution (U.S. Geological Survey, 1983). Results from these analyses were combined with those of regional flood frequency analyses (Zembrzuski and Dunn, 1979) to determine regionally weighted frequency curves. At miscellaneous sites and gaging stations with less than 10 years of record, only the regional equations were used.

Data in table 3 indicate that the most severe floods were in the Schoharie Creek and lower Hudson River basins; 15 of the peak discharges at sites in these basins had recurrence intervals equal to or greater than 25 years. Sites that had peak discharges with recurrence intervals greater than 100 years were Delaware River above Lackawaxen River near Barryville (01428500) and East Branch Neversink River at Denning (01434010). New peak discharges of record were set at eight gaging stations throughout the study area, six of which occurred at sites within the Schoharie Creek basin.

Several floods equal to or greater than the April 1987 flood have plagued the Catskill Mountain region in the past. Since stream gaging began in the early 1900's, notably widespread and damaging floods occurred in March 1936, September 1938, November 1950, March 1951, August and October 1955, and March 1980. Numerous others have inflicted damages in smaller, localized areas. Hydrographs for seven continuous-record gaging stations are presented in figures $6 \mathrm{~A}-6 \mathrm{G}$, which include other notable floods recorded in this century for comparison. The effect of reservoir storage on instantaneous peak flows is described below; more complete discussion of how the Catskill reservoirs in the New York City water-supply system modified daily flows is given in a later section.

\section{Description}

Unit discharge rates of the mountain streams in the early morning of April 4 ranged from 5 to $10\left(\mathrm{ft}^{3} / \mathrm{s}\right) / \mathrm{mi}^{2}$. The saturated soils and steep relief enabled a quick response to the developing storm, and runoff rates had begun to 

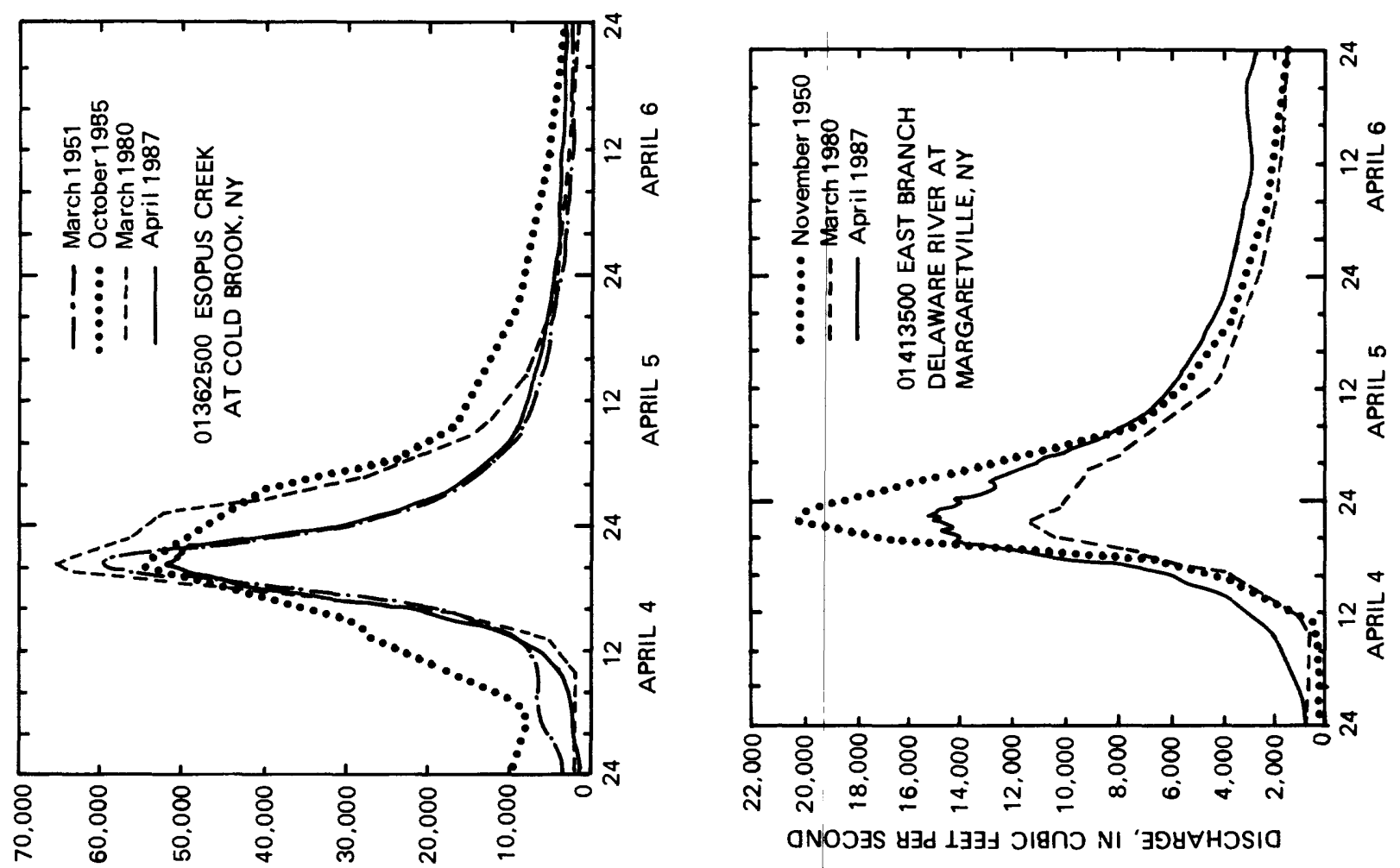

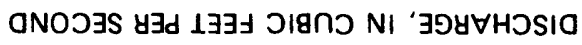
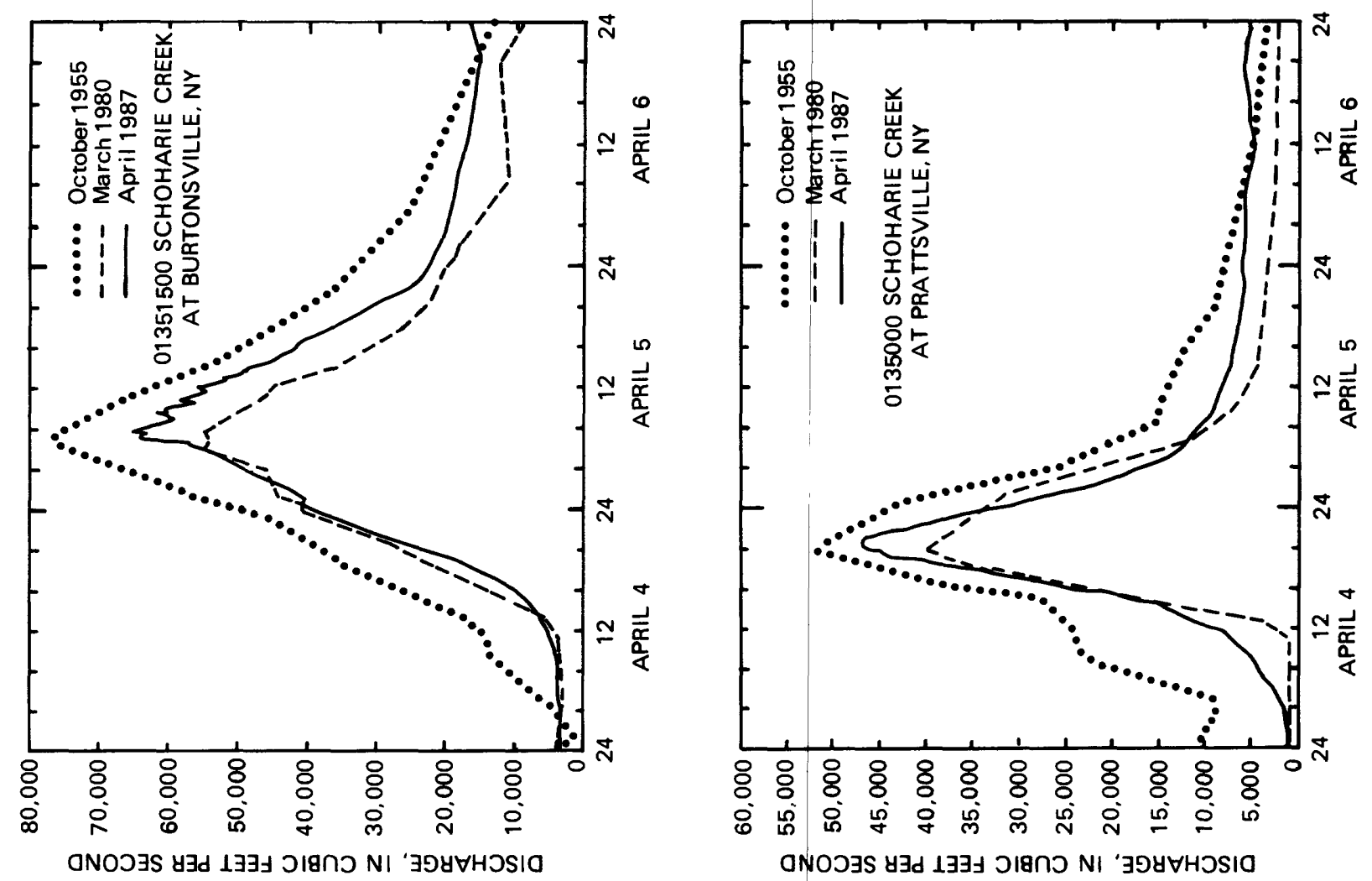

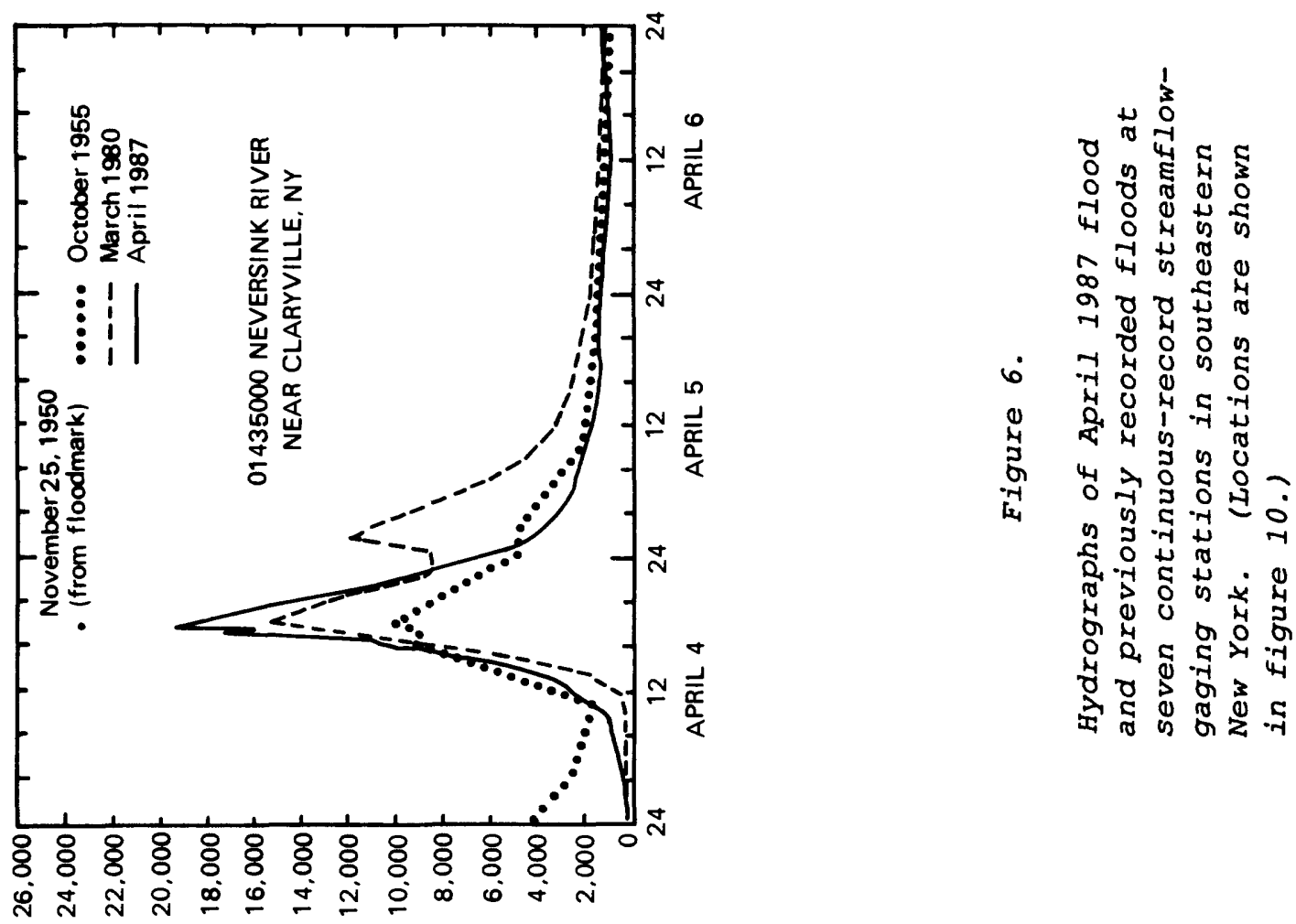

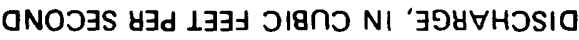

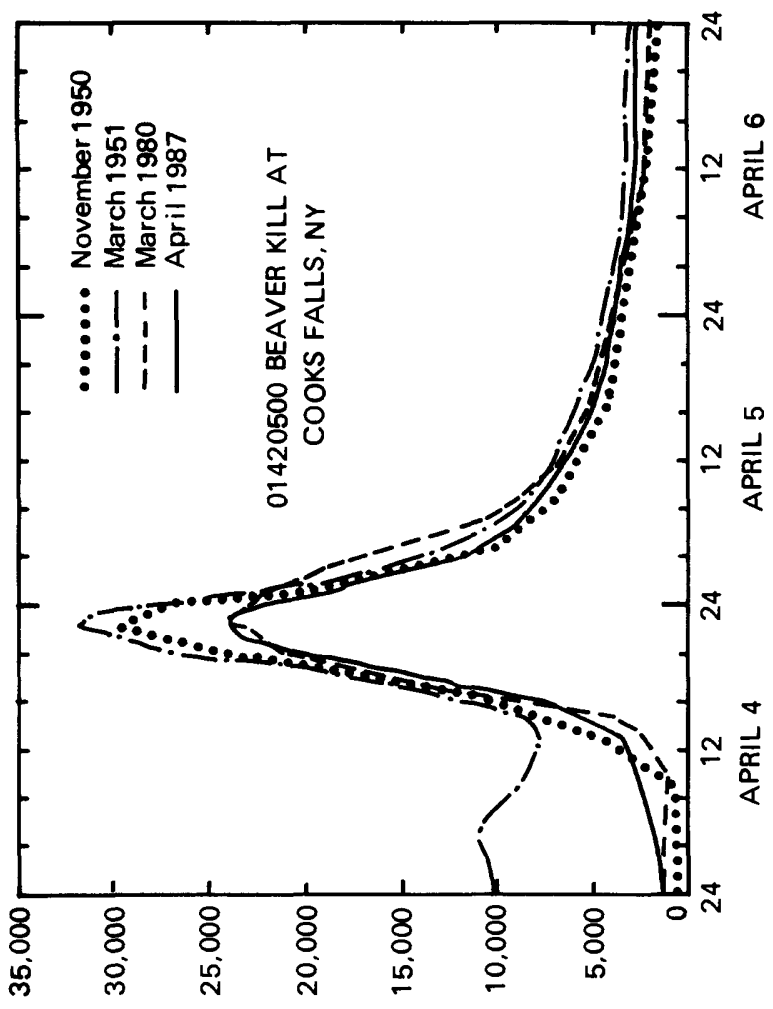

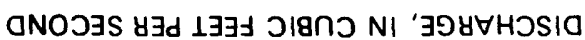

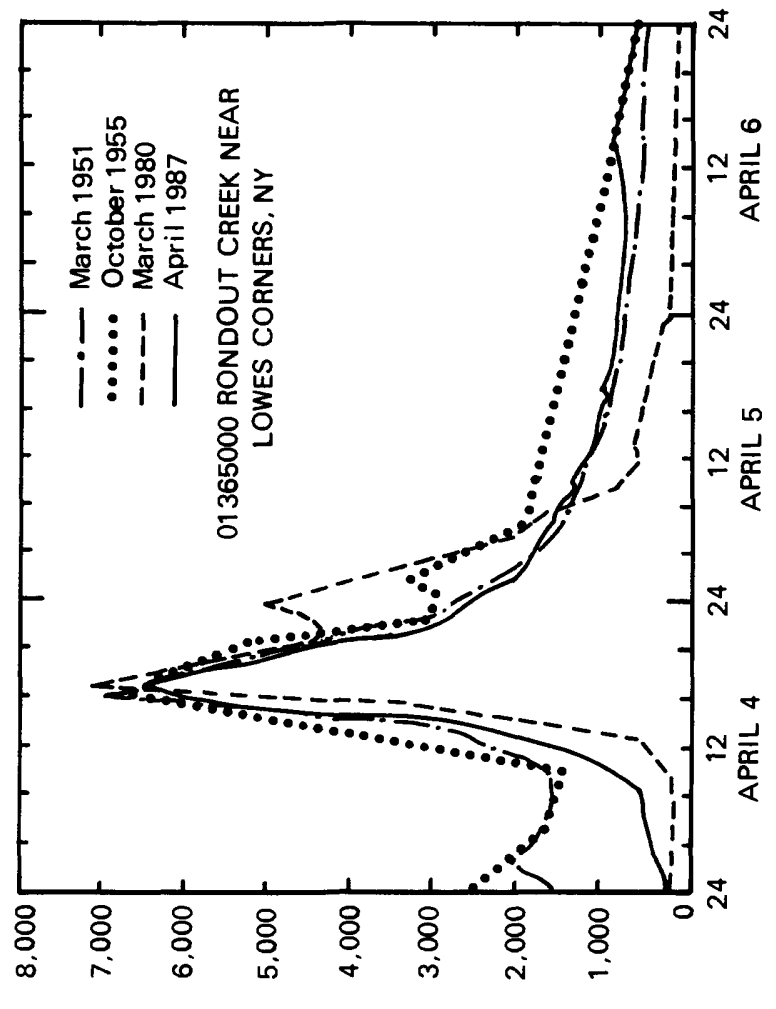

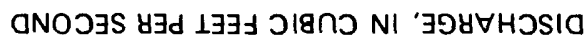


increase steadily by daybreak (fig. 6). By late afternoon, some streams were rising at rates that exceeded $2 \mathrm{ft} / \mathrm{h}$, and, after the rain began to slacken in early evening, runoff peaked at rates 20 to 40 times greater than when the rain began. Flood crests arrived along the lower reaches of the larger streams during the morning of April 5. The crests along some streams were delayed and attenuated by reservoirs.

The most severe flooding occurred along the main stems and tributaries of six streams: Schoharie Creek, Catskill Creek, Esopus Creek, Rondout Creek, East Branch Delaware River, and Neversink River (fig. 1). Flooding was less severe on the adjacent Mohawk River, West Branch Delaware River, Susquehanna River, and Wallkill River, as well as along streams that drain the lower Hudson River valley from the east (table 2).

Schoharie Creek Basin.--Floodwaters in the steep upper reaches of the Schoharie Creek basin generally peaked between 1800 hours and midnight on April 4 (table 2). Neither the Schoharie Reservoir nor the lower reservoir of the New York Power Authority (NYPA) Blenheim-Gilboa pumped-storage power project had a significant effect on the timing or magnitude of the crest. (The Schoharie Reservoir was full and spilling before the flood even began, and NYPA is required by orders in its operating license to pass incoming discharge to its lower reservoir without modification.) The crest did begin to attenuate as floodwaters spilled onto the broad, flat flood plains of the gentler sloped middle reach, however. The greatest discharge of Schoharie Creek probably occurred near the gaging station at Breakabeen (station 01350355, fig. 6), (163 $\left.\mathrm{ft}^{3} / \mathrm{s}\right) / \mathrm{mi}^{2}$ at 0030 on April 5. The peak at Burtonsville, the most downstream gaging station (01351500), arrived at 0745 hours on April 5. The greatest unit discharge measured in the Schoharie Creek basin was on the East Kill near Jewett Center (station 01349700), a tributary in the basin's headwaters, for which a rate of $320\left(\mathrm{ft}^{3} / \mathrm{s}\right) / \mathrm{mi}^{2}$ was calculated. At Burtonsville, the effects of natural attenuation reduced the unit peak discharge to $73.5\left(\mathrm{ft}^{3} / \mathrm{s}\right) / \mathrm{mi}^{2}$.

Catskill Creek basin.--The Catskill Creek basin has no continuous-record stations, but local residents reported that streams peaked during the evening of April 4. The greatest unit runoff rate of $300\left(\mathrm{ft}^{3} / \mathrm{s}\right) / \mathrm{mi}^{2}$ was confined to the headwater tributary at Franklinton. Downstream tributaries contributed from 100 to $160\left(\mathrm{ft}^{3} / \mathrm{s}\right) / \mathrm{mi}^{2}$.

Esopus Creek basin.--Tributary streams and the main stem upstream from Ashokan Reservoir in the Esopus Creek basin crested by 2100 hours on April 4 at unit discharge rates ranging from about 90 to $290\left(\mathrm{ft}^{3} / \mathrm{s}\right) / \mathrm{mi}^{2}$. The Ashokan Reservoir had a substantial effect on delaying and reducing the flood peak in the downstream reaches (table 3 ).

Rondout Creek basin.--The upper Rondout Creek and its tributaries peaked by 1800 hours on April 4. Because a large proportion of the uncontrolled drainage area of Rondout Creek is downstream from the Rondout Reservoir, the attenuating effect of the Reservoir was limited to the upper reaches of the Creek. 
East Branch Delaware River basin.--Although flood damage was extensive along the East Branch Delaware River upstream from Pepacton Reservoir, unit runoff rates recorded in this area generally were the smallest of any of the flooded areas, ranging from about 40 to $100\left(\mathrm{ft}^{3} / \mathrm{s}\right) / \mathrm{mi}^{2}$. Most streams peaked between 2000 and 2200 hours on April 4. Pepacton Reservoir had the capacity to store enough flood runoff to delay spilling until April 7 . Because total storm rainfall had been less downstream from Pepacton Reservoir, only minor flooding occurred on the lower reaches of the East Branch Delaware River.

Neversink River basin.--The highest unit runoff rates recorded in the Catskill region were south and west of slide Mountain, in the headwaters of the Neversink River basin, where they ranged from about 260 to 400

$\left(\mathrm{ft}^{3} / \mathrm{s}\right) / \mathrm{mi}^{2}$. Flood peaks occurred between 1600 and 1900 hours on April 4. Like Pepacton Reservoir, Neversink Reservoir had sufficient storage capacity to store storm runoff without spilling until April 7. Flooding of the Neversink River downstream from Neversink Reservoir was insignificant.

\section{Table 2.--Drainage area, capacity, and surface area of Catskill Reservoirs in the New York City water-supply system}

[Data from Firda and others, 1986, and Greeson and Robison, 1970. Locations are shown in fig. 1.]

\begin{tabular}{|c|c|c|c|c|}
\hline Reservoir & Drai & $\begin{array}{l}\text { inage area } \\
\text { (square } \\
\text { miles) }\end{array}$ & $\begin{array}{c}a_{\text {Usable capacity }} \\
\text { (billions of } \\
\text { cubic feet) }\end{array}$ & $\begin{array}{c}{ }^{\mathrm{b}} \text { Surface area } \\
\text { (square } \\
\text { miles) }\end{array}$ \\
\hline Schoharie & Schoharie Creek & 314 & 2.618 & 1.79 \\
\hline Ashokan & Esopus Creek & 256 & $c_{17.095}$ & $c_{12.38}$ \\
\hline Rondout & Rondout Creek & 94 & 6.691 & 3.28 \\
\hline Pepacton & $\begin{array}{l}\text { East Branch Delaware } \\
\text { River }\end{array}$ & 371 & 18.743 & 8.90 \\
\hline Cannonsville & $\begin{array}{l}\text { West Branch Delaware } \\
\text { River }\end{array}$ & 454 & 12.796 & 7.50 \\
\hline Neversink & Neversink River & 92 & 4.672 & 2.30 \\
\hline
\end{tabular}

a Storage between minimum operating level and crest of spillway.

b At spillway level.

c Combined total of east and west basins.

\section{Effect of Reservoirs}

The Catskill Mountain region has no major flood-control reservoirs, but the six Catskill reservoirs that are part of the New York City water-supply system can sometimes attenuate incoming flood discharges. The degree to which these reservoirs attenuate and delay flood peaks is a function of available storage at the onset of flooding; the reservoirs have no provision for planned regulation of floodflows, and the amount they are able to divert through water-supply tunnels is inconsequential in relation to flood volumes. Pertinent reservoir data are given in table 2. 
Winter and spring runoff generally fills the reservoirs by May 1. Normally, the system is at 90 percent of capacity by the end of March. On March 30, 1987, the system was at 95.1 percent of capacity (New York City Department of Environmental Protection, oral commun., March, 1987). The extent to which the daily mean discharge of each reservoir's inflow was modified is illustrated in figure 7 . Daily inflow was calculated, on the assumption of conservation of mass, by the equation

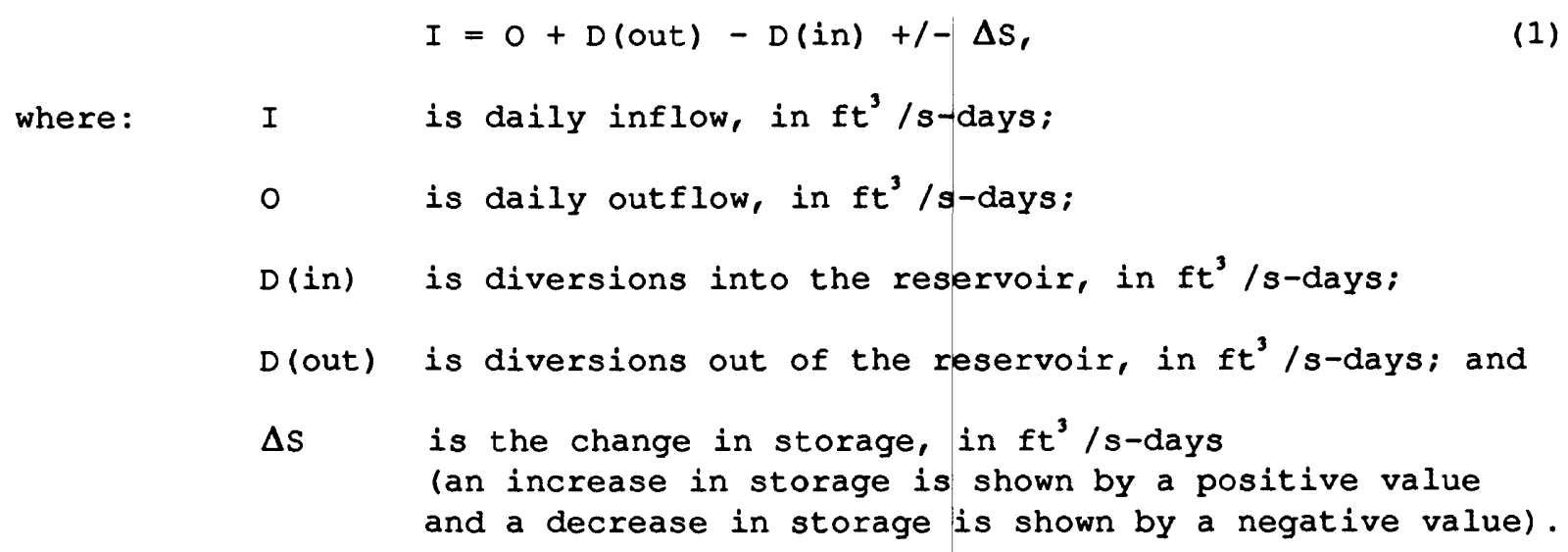

The New York City Department of Environmental Protection supplied diversion data for each Catskill reservoir, storage data for all but Schoharie Reservoir, and outflow and calculated inflow for Rondout and Ashokan Reservoirs. The U.S. Geological Survey provided all other data.

The Schoharie Reservoir was full and spilling when the storm began on April 3. This condition, in combination with the reservoir's relatively small size, caused little attenuation of incoming floodwaters (fig. 7A); the daily outflow on April 4 was 94 percent of the daily inflow. The Cannonsville Reservoir, which also was spilling when the storm began, modified inflow somewhat because of its relatively large size (fig. 7B and table 2). Its maximum daily outflow (April 6) was reduced to 85 percent of the inflow (April 5).

Both the Rondout and Ashokan Reservoirs filled and began to spill during the day on April 4 (fig. 7C, 7D). The maximum daily outflow to Rondout Creek also occurred that day but was reduced to 48 percent of the inflow. The maximum daily outflow of the Ashokan Reservoir to Esopus Creek was delayed until April 5 and was reduced to 66 percent of the inflow of the day before.

The reservoirs that most affected downstream floodflows were the Pepacton and the Neversink (fig. 7E, 7F). The maximum daily inflow to both reservoirs occurred on April 4. The Pepacton Reservoir did not completely fill until April 7, and the maximum daily outflow (April 9) was only 16 percent of the inflow on April 4. The Neversink Reservoir spilled on April 6. Its maximum daily outflow (April 7) was 12 percent of the April 4 inflow. 


\section{SCHOHARIE CREEK FLOOD PROFILES}

The most extensive flood losses in April 1987 occurred along the mainstem of Schoharie Creek. Scores of homes, farms, and businesses were inundated in Middleburg, Schoharie, and other villages. The collapse of the New York State Thruway bridge provided the tragic climax to the weekend of flooding.

Since at least the early 1900's, only the flood of october 1955 exceeded the April 1987 flood in magnitude in the middle and lower reaches of Schoharie Creek. In the upper reach, both the November 1950 and October 1955 flood discharges exceeded the 1987 flood in magnitude, and, at the Prattsville gaging station (01350000, fig. 10, p. 43), the ice-jam floods in January 1978 and March 1979 exceeded the stage of the 1987 flood.

After the 1955 flood, the U.S. Geological Survey obtained and compiled elevations of high-water marks along Schoharie Creek from near its mouth to Lexington (Bogart, 1960). In April 1987, the U.S. Geological Survey again surveyed high-water marks along the creek to document the recent flood and to draw comparisons between it and the larger 1955 flood. Flood marks were identified along approximately $83 \mathrm{mi}$ of the creek, from near the mouth to the village of Hunter, at the upstream and downstream sides of bridges and dams, at major tributaries, and at gaging stations and miscellaneous sites. The marks were later referenced to National Geodetic Vertical datum of 1929, compiled, and plotted together with 1955 floodmarks on profiles of the creek (figs. 8A-8Q). The locations (river mile) of bridges, dams, and tributaries, and the elevations of the low-water-surface profile and dam crests were obtained from U.S. Geological Survey topographic maps. Low-chord and road elevations of bridges were measured in the field or obtained from floodinsurance studies previously prepared by the U.S. Department of Housing and Urban Development. The locations (river mile) of the gaging stations and major geographic features along Schoharie Creek are shown in figure 9 (p. 33 ).

Accuracy ratings were assigned to the high-water marks when they were identified in the field. Both the nature of the mark and the environment in which it was found were considered during assessment of its accuracy. Seed lines or fine debris lines on trees or buildings distant from the main stream provided the best floodmarks. A "poor" rating would be assigned to eroded sections of the bank (washlines) or nondescript piles of debris. The following guide can be used to quantify these sometimes subjective ratings:

Rating
excellent
good
fair
peor

\begin{tabular}{cc} 
Accuracy $(\mathrm{ft})$ \\
\hline$+/-$ & 0.02 \\
$+/-$ & 0.05 \\
$+/-$ & 0.10 \\
$2+/-$ & 0.10 \\
\hline
\end{tabular}



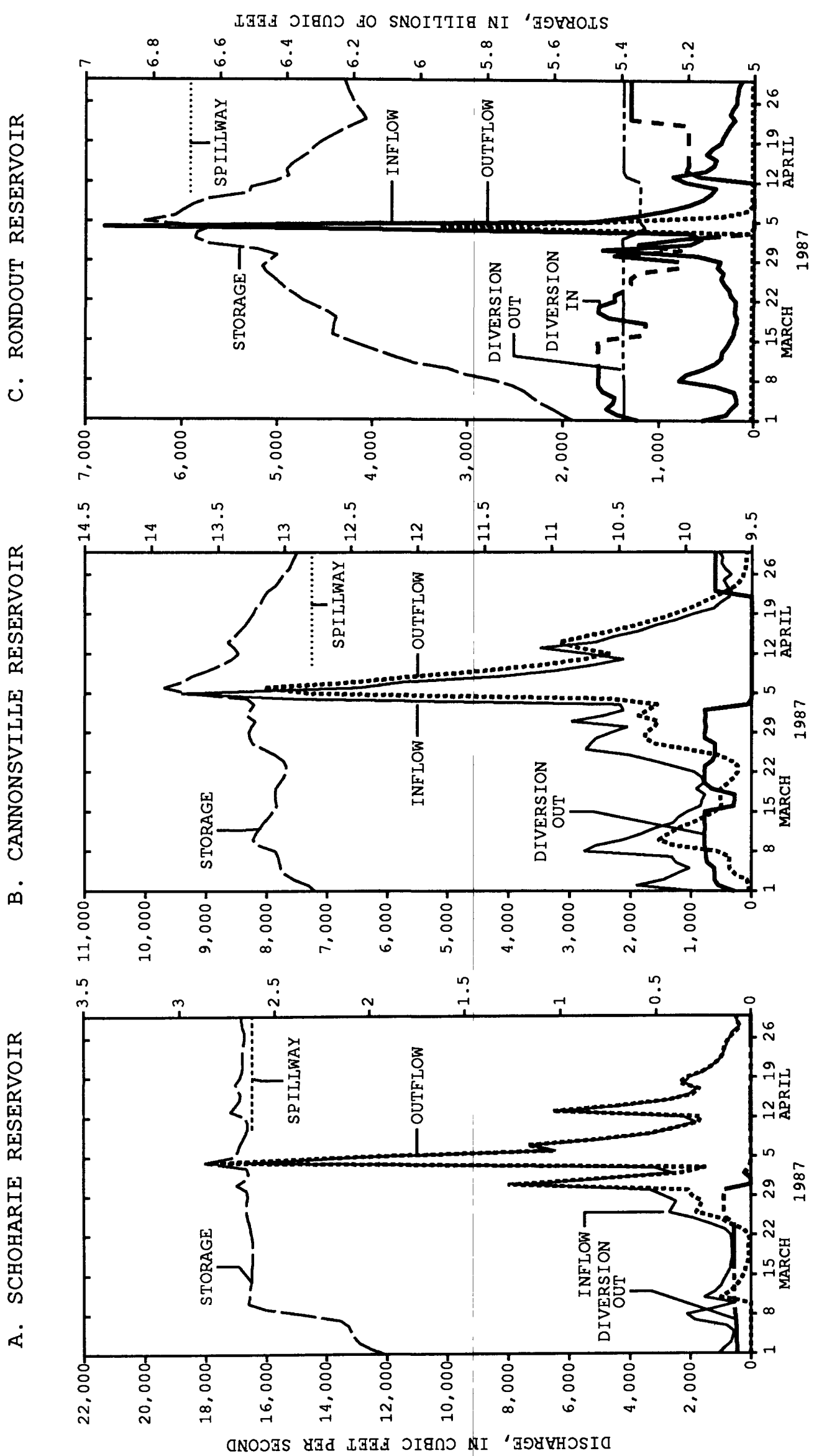

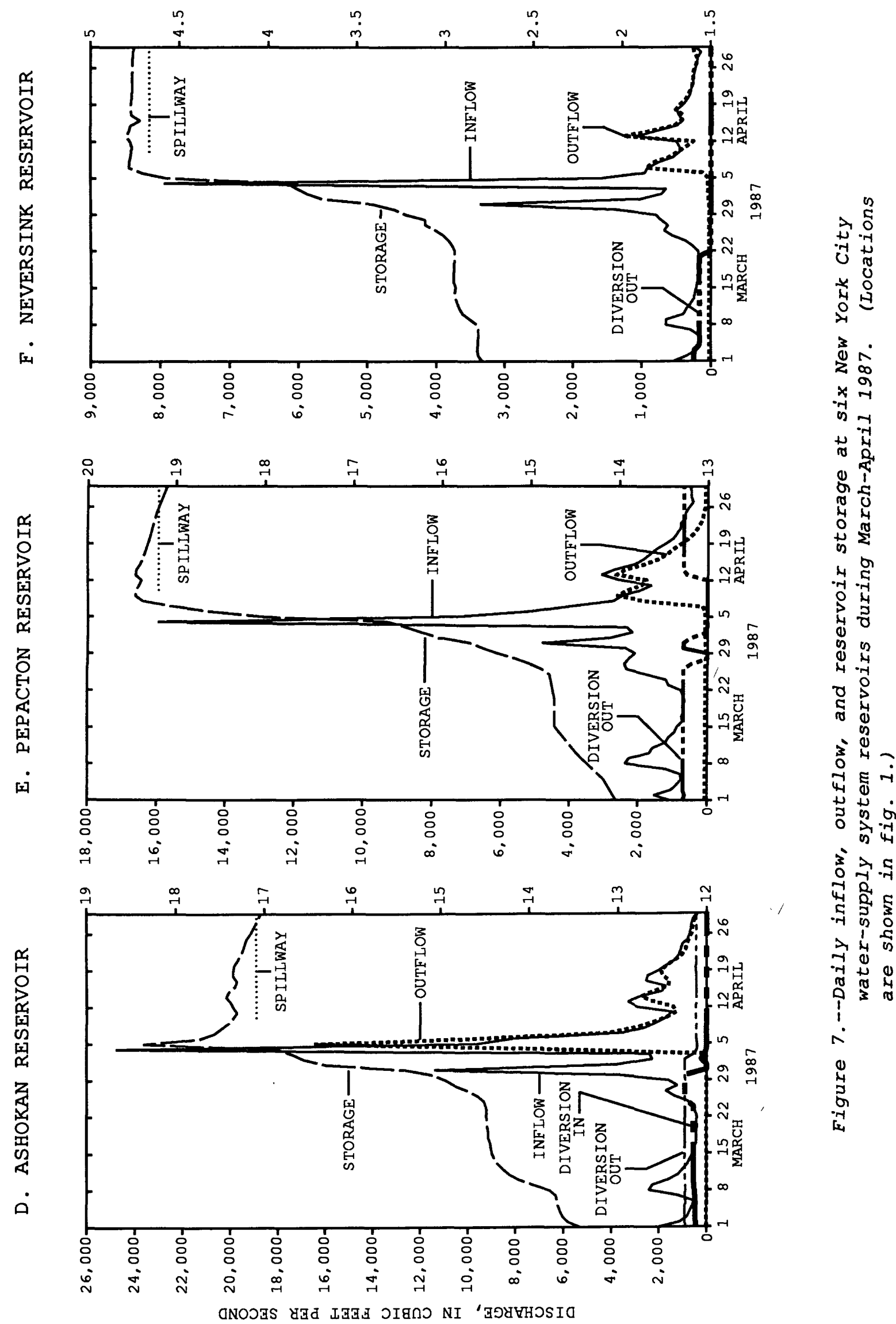

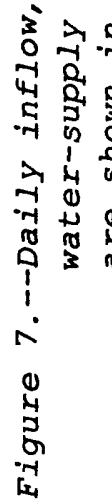



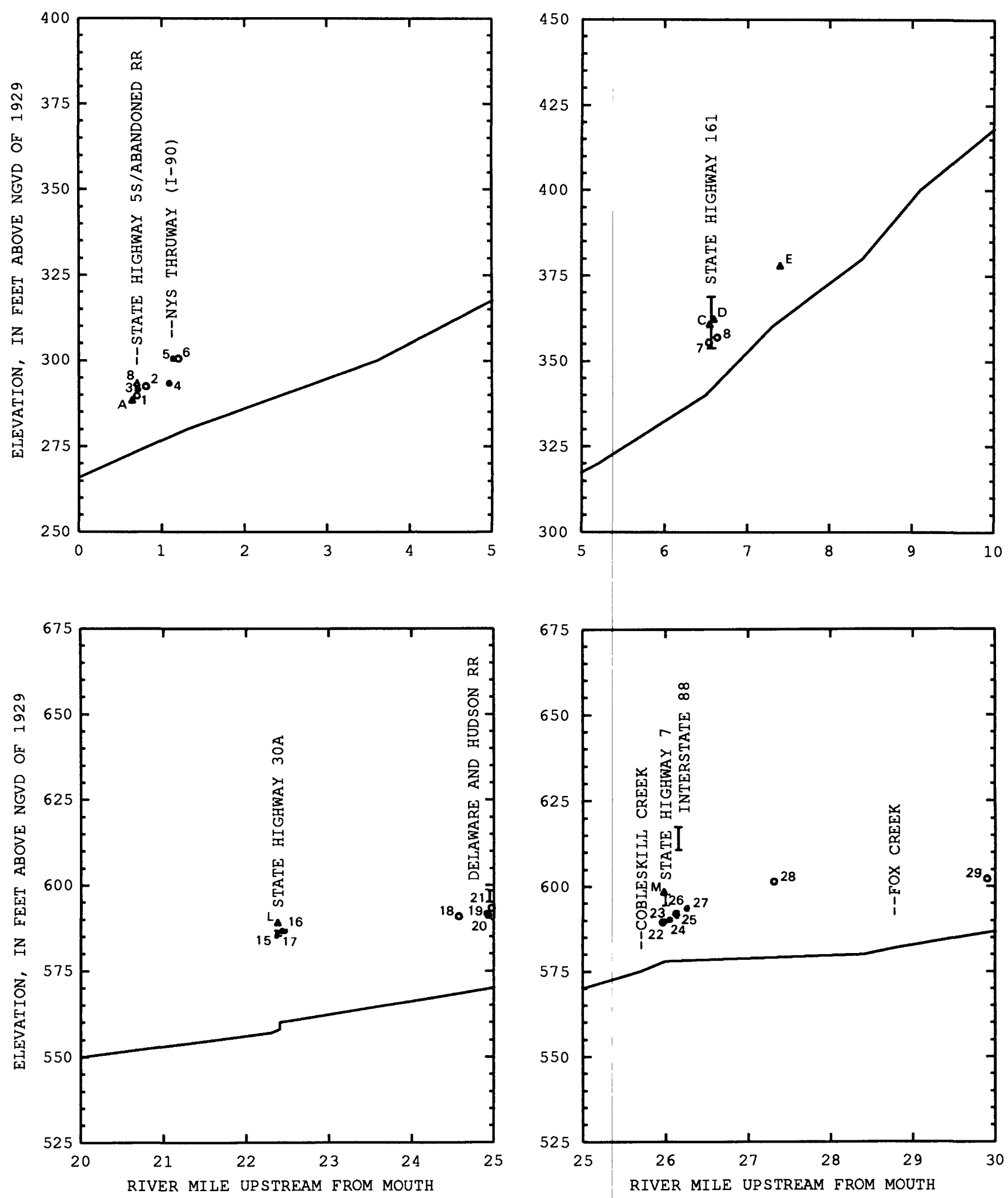

Figure 8.--Low-water-surface profiles of Schoharie Creek with floodmarks from October 1955 and April 1987, by 5-mile increments from the mouth. (Locations are shown in fig. 9.) 

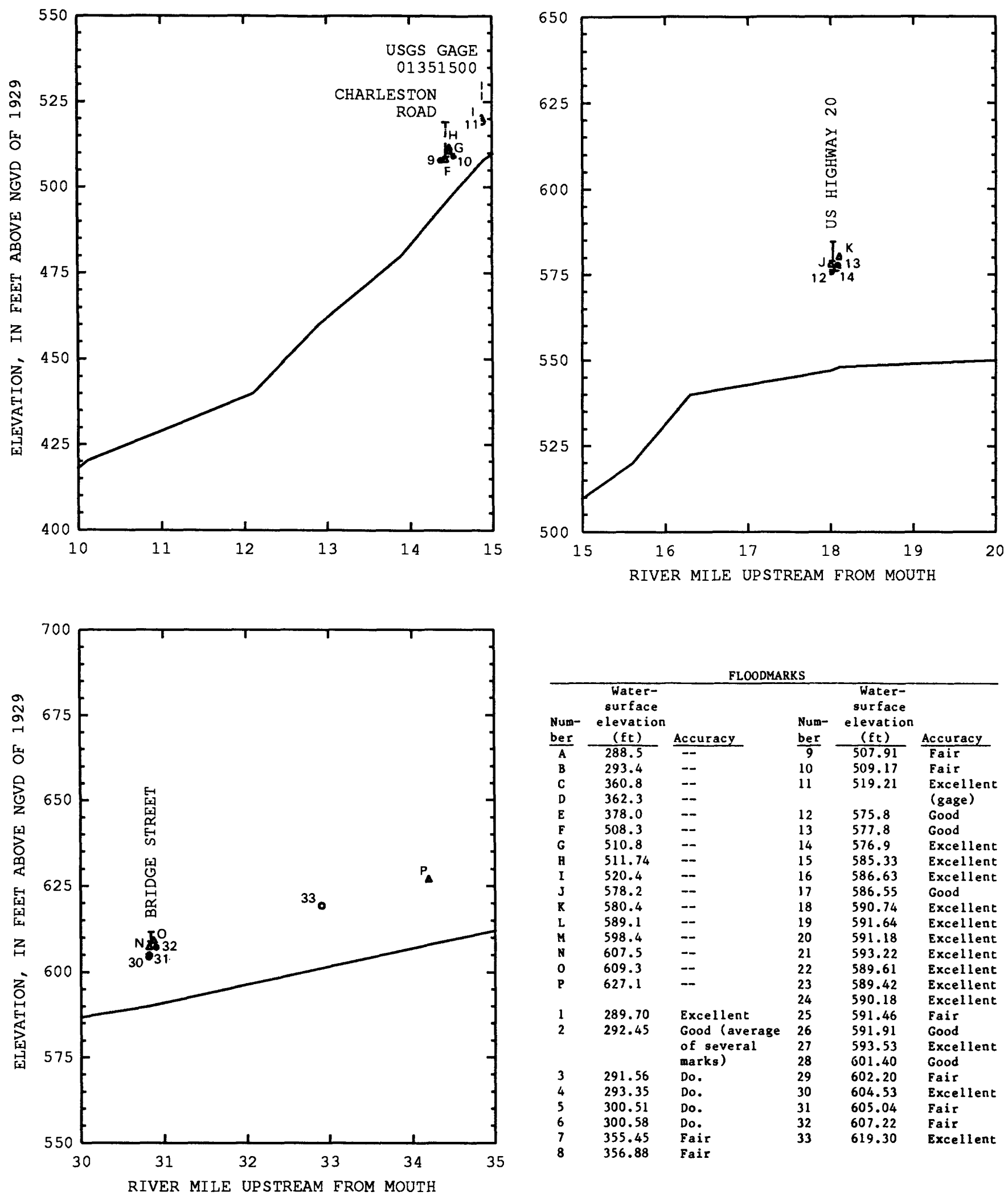

\begin{tabular}{|c|c|c|c|c|c|}
\hline \multicolumn{6}{|c|}{ FLOODMARKS } \\
\hline $\begin{array}{l}\text { Num- } \\
\text { ber }\end{array}$ & $\begin{array}{l}\text { Water- } \\
\text { surface } \\
\text { elevation } \\
\text { (ft) }\end{array}$ & Accuracy & $\begin{array}{l}\text { Num- } \\
\text { ber }\end{array}$ & $\begin{array}{l}\text { Water- } \\
\text { surface } \\
\text { elevation } \\
\text { (ft) }\end{array}$ & Accuracy \\
\hline $\bar{A}$ & 288.5 & -- & 9 & 507.91 & Fair \\
\hline B & 293.4 & -- & 10 & 509.17 & Fair \\
\hline C & 360.8 & -- & 11 & 519.21 & Excellent \\
\hline$D$ & 362.3 & -- & & & (gage) \\
\hline $\mathbf{E}$ & 378.0 & -- & 12 & 575.8 & Good \\
\hline $\mathbf{F}$ & 508.3 & -- & 13 & 577.8 & Good \\
\hline G & 510.8 & -- & 14 & 576.9 & Excellent \\
\hline $\mathrm{H}$ & 511.74 & -- & 15 & 585.33 & Excellent \\
\hline I & 520.4 & -- & 16 & 586.63 & Excellent \\
\hline J & 578.2 & -- & 17 & 586.55 & Good \\
\hline $\mathbf{R}$ & 580.4 & -- & 18 & 590.74 & Excellent \\
\hline L & 589.1 & -- & 19 & 591.64 & Excellent \\
\hline M & 598.4 & -- & 20 & 591.18 & Excellent \\
\hline N & 607.5 & -- & 21 & 593.22 & Excellent \\
\hline 0 & 609.3 & -- & 22 & 589.61 & Excellent \\
\hline $\mathbf{P}$ & 627.1 & - & $\begin{array}{l}23 \\
24\end{array}$ & $\begin{array}{l}589.42 \\
590.18\end{array}$ & $\begin{array}{l}\text { Excellent } \\
\text { Excellent }\end{array}$ \\
\hline 1 & 289.70 & Excellent & 25 & 591.46 & Fair \\
\hline 2 & 292.45 & $\begin{array}{l}\text { Good (average } \\
\text { of several } \\
\text { marks) }\end{array}$ & $\begin{array}{l}26 \\
27 \\
28\end{array}$ & $\begin{array}{l}591.91 \\
593.53 \\
601.40\end{array}$ & $\begin{array}{l}\text { Good } \\
\text { Excellent } \\
\text { Good }\end{array}$ \\
\hline 3 & 291.56 & Do. & 29 & 602.20 & Fair \\
\hline 4 & 293.35 & Do. & 30 & 604.53 & Excellent \\
\hline 5 & 300.51 & Do. & 31 & 605.04 & Fair \\
\hline 6 & 300.58 & Do. & 32 & 607.22 & Fair \\
\hline 7 & 355.45 & Fair & 33 & 619.30 & Excellent \\
\hline 8 & 356.88 & Fair & & & \\
\hline
\end{tabular}

\footnotetext{
Figure 8.--Low-water-surface profiles of Schoharie Creek with floodmarks from October 1955 and April 1987, by 5-mile increments from the mouth. (continued)
} 

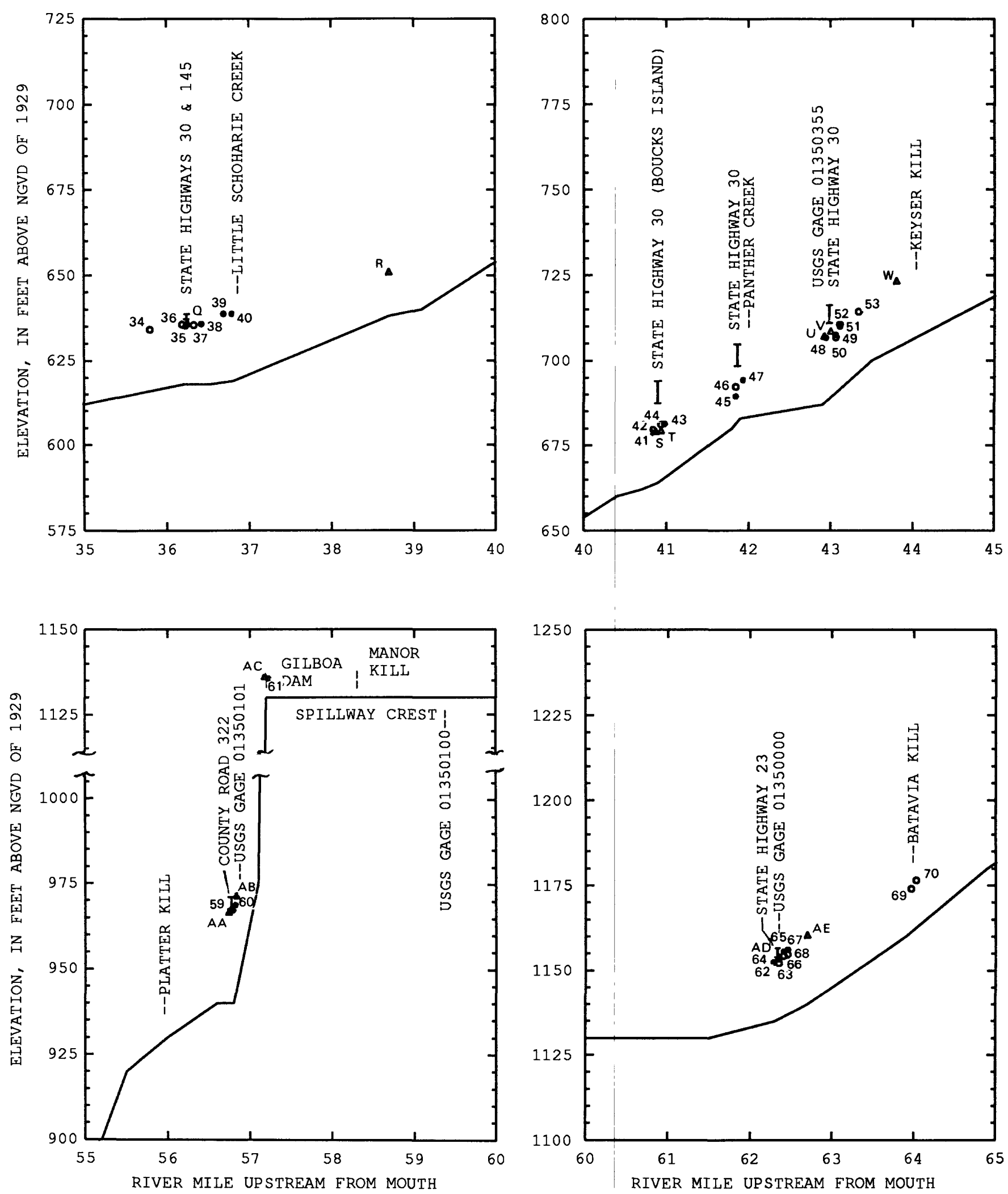

Figure 8.--Low-water-surface profiles of Schoharie Creek with floodmarks from October 1955 and April 1987, by 5-mile increments from the mouth. (continued) 

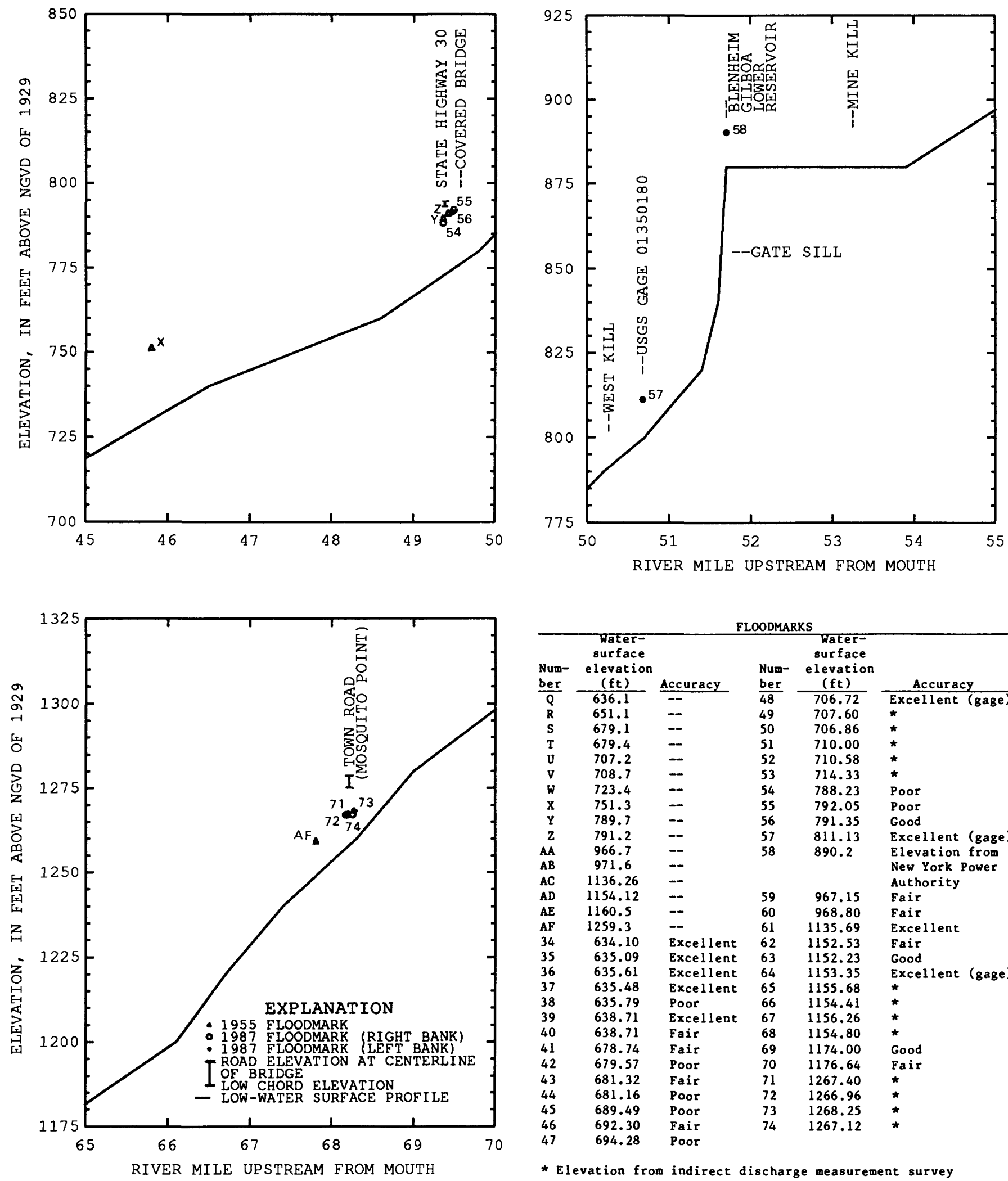

\begin{tabular}{|c|c|c|c|c|c|}
\hline \multicolumn{6}{|c|}{ FLOODMARKS } \\
\hline $\begin{array}{l}\text { Num- } \\
\text { ber }\end{array}$ & $\begin{array}{l}\text { water- } \\
\text { surface } \\
\text { elevation } \\
(f t)\end{array}$ & Accuracy & $\begin{array}{l}\text { Num- } \\
\text { ber }\end{array}$ & $\begin{array}{l}\text { Water- } \\
\text { surface } \\
\text { elevation } \\
(\mathrm{ft})\end{array}$ & Accuracy \\
\hline $\bar{Q}$ & 636.1 & -- & $\overline{48}$ & 706.72 & Excellent (gage) \\
\hline $\mathbf{R}$ & 651.1 & - & 49 & 707.60 & * \\
\hline s & 679.1 & -- & 50 & 706.86 & * \\
\hline $\mathbf{T}$ & 679.4 & - & 51 & 710.00 & $\star$ \\
\hline $\mathbf{U}$ & 707.2 & - & 52 & 710.58 & $\star$ \\
\hline $\mathbf{v}$ & 708.7 & - & 53 & 714.33 & * \\
\hline $\mathbf{W}$ & 723.4 & - & 54 & 788.23 & Poor \\
\hline $\mathrm{X}$ & 751.3 & - & 55 & 792.05 & Poor \\
\hline $\mathbf{Y}$ & 789.7 & - & 56 & 791.35 & Good \\
\hline $\mathbf{Z}$ & 791.2 & -- & 57 & 811.13 & Excellent (gage) \\
\hline $\mathbf{A A}$ & 966.7 & - & 58 & 890.2 & Elevation from \\
\hline $\mathbf{A B}$ & 971.6 & - & & & New York Power \\
\hline$A C$ & 1136.26 & - & & & Authority \\
\hline$A D$ & 1154.12 & -- & 59 & 967.15 & Fair \\
\hline$A E$ & 1160.5 & -- & 60 & 968.80 & Fair \\
\hline $\mathbf{A F}$ & 1259.3 & -- & 61 & 1135.69 & Excellent \\
\hline 34 & 634.10 & Excellent & 62 & 1152.53 & Fair \\
\hline 35 & 635.09 & Excellent & 63 & 1152.23 & Good \\
\hline 36 & 635.61 & Excellent & 64 & 1153.35 & Excellent (gage) \\
\hline 37 & 635.48 & Excellent & 65 & 1155.68 & $\star$ \\
\hline 38 & 635.79 & Poor & 66 & 1154.41 & $\star$ \\
\hline 39 & 638.71 & Excellent & 67 & 1156.26 & * \\
\hline 40 & 638.71 & Fair & 68 & 1154.80 & $\star$ \\
\hline 41 & 678.74 & Fair & 69 & 1174.00 & Good \\
\hline 42 & 679.57 & Poor & 70 & 1176.64 & Fair \\
\hline 43 & 681.32 & Fair & 71 & 1267.40 & $\star$ \\
\hline 44 & 681.16 & Poor & 72 & 1266.96 & $\star$ \\
\hline 45 & 689.49 & Poor & 73 & 1268.25 & * \\
\hline 46 & 692.30 & Fair & 74 & 1267.12 & $\star$ \\
\hline 47 & 694.28 & Poor & & & \\
\hline
\end{tabular}

* Elevation from indirect discharge measurement survey

Figure 8.--Low-water-surface profiles of Schoharie Creek with floodmarks from October 1955 and April 1987, by 5-mile increments from the mouth. (continued) 

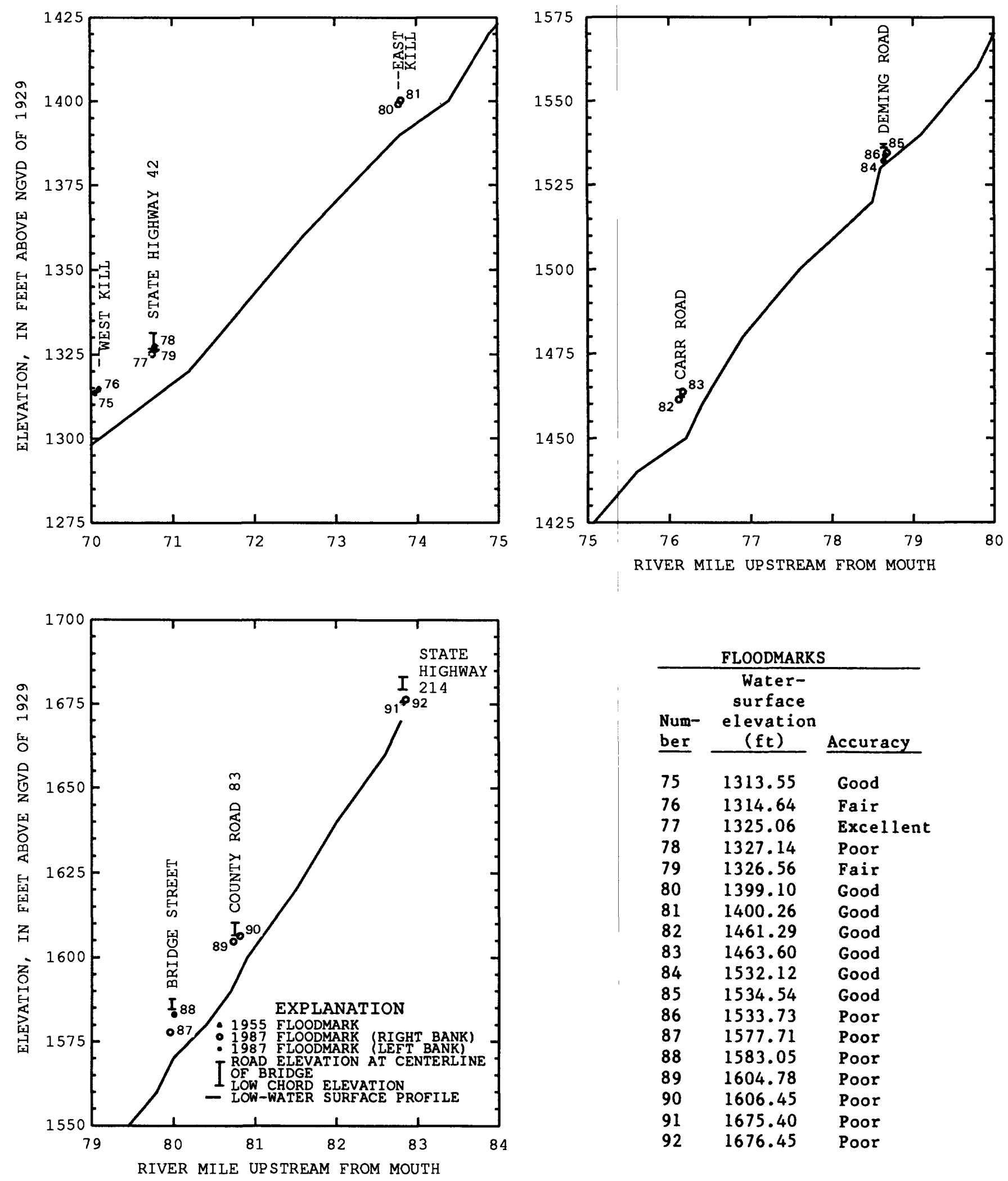

\begin{tabular}{|c|c|c|}
\hline \multicolumn{3}{|c|}{ FLOODMARKS } \\
\hline $\begin{array}{l}\text { Num- } \\
\text { ber }\end{array}$ & $\begin{array}{c}\text { Water- } \\
\text { surface } \\
\text { elevation } \\
(f t) \\
\end{array}$ & Accuracy \\
\hline 75 & 1313.55 & Good \\
\hline 76 & 1314.64 & Fair \\
\hline 77 & 1325.06 & Excellent \\
\hline 78 & 1327.14 & Poor \\
\hline 79 & 1326.56 & Fair \\
\hline 80 & 1399.10 & Good \\
\hline 81 & 1400.26 & Good \\
\hline 82 & 1461.29 & Good \\
\hline 83 & 1463.60 & Good \\
\hline 84 & 1532.12 & Good \\
\hline 85 & 1534.54 & Good \\
\hline 86 & 1533.73 & Poor \\
\hline 87 & 1577.71 & Poor \\
\hline 88 & 1583.05 & Poor \\
\hline 89 & 1604.78 & Poor \\
\hline 90 & 1606.45 & Poor \\
\hline 91 & 1675.40 & Poor \\
\hline 92 & 1676.45 & Poor \\
\hline
\end{tabular}

Figure 8.--Low-water-surface profiles of Schoharie Creek with floodmarks from October 1955 and April 1987, by 5-mile increments from the mouth. (continued) 


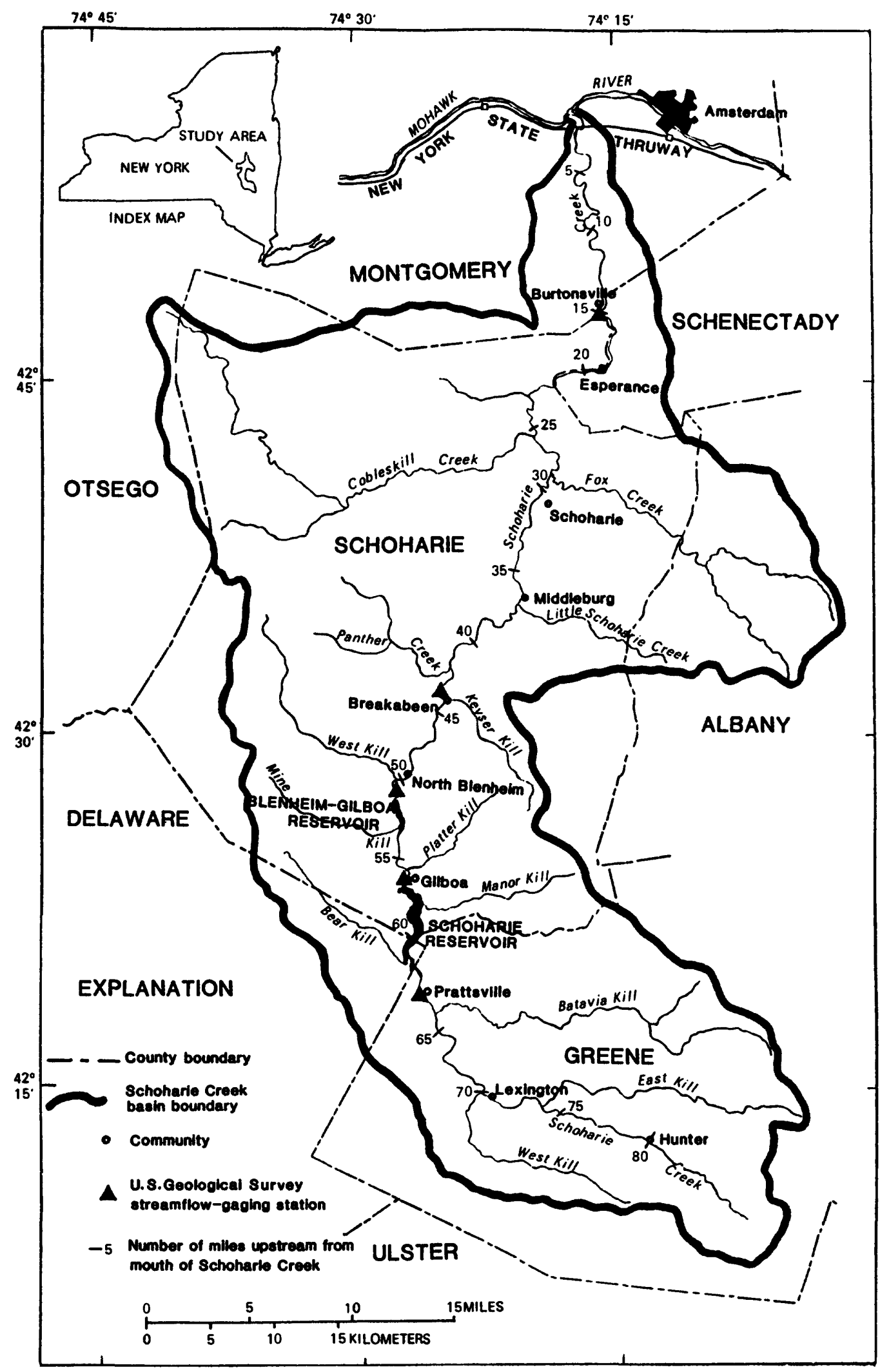

Base from U.S. Geological Survey Binghamton, NY, 1:250,000, 1948

Figure 9.--Locations of gaging stations and major geographic features along Schoharie Creek. 


\section{SUMMARY}

Five counties in southeastern New York were declared major disaster areas after intense rainfall on April 3-5, 1987, caused widespread flooding. Severe frontal storms often cause flooding in the narrow, steep valleys of the Catskill Mountains. This storm occurred at a time when soils were saturated, reservoir storage was near capacity, and stream discharge was high from snowmelt. Rainfall during the storm period totaled 9.09 in. at Slide Mountain and 8.20 in. at Tannersville. Schoharie, Catskill, Esopus, and Rondout Creeks and East Branch Delaware and Neversink Rivers and their tributaries under went the most severe flooding.

Reservoirs in the area are not designed as flood-control facilities but can sometimes modify incoming flood discharges, depending on their available storage. Cannonsville, Ashokan, Rondout, Pepacton, and Neversink Reservoirs decreased downstream floodflows by reducing outflows to $85,66,48,16$ and 12 percent of inflows, respectively. Schoharie Reservoir had little effect on peak flows.

Ten lives were lost when a New York State Thruway bridge collapsed into the creek as a result of streambed scouring. Damage exceeded $\$ 65$ million. Homes, farms, and businesses along Schoharie Creek were especially hard hit. only two other recorded floods along Schoharie Creek were of greater magnitude--the floods of November 1950 in the upper reach and of october 1955 along the entire reach. Ice-jam floods at Prattsville in January 1978 and March 1979 exceeded the 1987 flood stages.

\section{SELECTED REFERENCES}

Bogart, D. B., 1960, Floods of August-october 1955, New England to North Carolina: U.S. Geological Survey Water-Supply Paper 1420, 854 p.

Council on Environmental Quality, 1975, The Delaware River basin--an environmental assessment of three centuries of change: Council on Environmental Quality, $87 \mathrm{p}$.

Dunn, Bernard, and Crippen, J. R., 1956, Flodds of August 1955 in New York: U.S. Geological Survey flood memorandum report no. 32, 23 p.

Eggleston, K. L., 1987a, New York climate, March 1987: Ithaca, N.Y., Cornell University, Northeast Regional Climate Center, 13 p.

1987b, New York climate, April 1987: Ithaca, N.Y., Cornell University, Northeast Regional Climate Center, $15 \mathrm{p}$.

Fenneman, N. M., 1938, Physiography of eastern United States: New York, McGraw-Hill, Inc., $714 \mathrm{p}$. 


\section{SELECTED REFERENCES (Continued)}

Firda, G. D., Lumia, Richard, Archer, R. J., and Burke, P. M., 1986, Water resources data, New York, water year 1985, volume 1, eastern New York excluding Long Island: U.S. Geological Survey Water-Data Report NY-85-1, 268 p.

Greeson, P. E., and Robison, F. L., 1970, Characteristics of New York Lakes (gazetteer): New York State Department of Environmental Conservation Bulletin $68,124 \mathrm{p}$.

McDonald, C. C., 1938, Floods of July and August 1938, Catskill Mountain region, New York: Albany, N.Y., U.S. Geological Survey open-file report, $20 \mathrm{p}$.

Monis, J. P., 1956, Floods of October 15-16, 1955 in southeastern New York with notes on the flood of October 30, 1955: Albany, N.Y., U.S. Geological Survey flood memorandum report no. 33, $17 \mathrm{p}$.

National Oceanic and Atmospheric Administration, 1978, Climate of New York: Climatography of the United States, no. $60,28 \mathrm{p}$. 1987a, Climatological data, New York, March 1987, v. 99, no. 3, 35 p. 1987b, Climatological data, New York, April 1987, v. 99, no. 4, 36 p. 1987c, Hourly precipitation data, New York, April 1987, v. 37, no. 4, $28 \mathrm{p}$.

National Transportation Safety Board, 1988, Collapse of New York State Thruway (I-90) bridge over the Schoharie Creek, near Amsterdam, New York, April 5, 1987: Washington, D.C., National Transportation Safety Board report NTSB/HAR-88/02, $169 \mathrm{p}$.

New England-New York Inter-Agency Committee, 1954, The resources of the New England-New York region, chap. XXXVII: New England-New York Inter-Agency Committee, $39 \mathrm{v}$.

U.S. Army Corps of Engineers, 1975, Review of reports for flood control, Mohawk River and Catskill Creek basins, New York: U.S. Army Corps of Engineers, New York District, $77 \mathrm{p}$.

U.S. Department of Agriculture, 1950, Delaware River watershed, New York, Pennsylvania, New Jersey, Delaware, and Maryland: U.S. Department of Agriculture, $21 \mathrm{p}$.

U.S. Department of Commerce, Weather Bureau, 1961, Rainfall frequency atlas of the United States: Washington D.C., Technical Paper no. 40, 115 p.

U.S. Geological Survey, 1958, Floods of 1950-51 in the Catskill Mountain region, New York, in U.S. Geological Survey 1957, Floods of 1951: U.S. Geological Survey Water-Supply Paper 1227, p. 201-277. 


\section{SELECTED REFERENCES (Continued)}

U.S. Geological Survey, 1983, Guidelines for determining flood-flow frequency: Interagency Advisory Committee on Water Data, Bulletin 17B of Hydrology Subcommittee, $28 \mathrm{p}$.

1986, National water summary 1985--hydrologic events and surface-water resources: U.S. Geological Survey Water-Supply Paper 2300, 506 p. (New York State section, p. 347-354).

Wagner, L. A., 1982, Drainage areas of New York streams, by river basins, a stream gazetteer, Part 1--data compiled as of October 1980: U.S. Geological Survey Water-Resources Investigations Open-File Report $81-1055,359 \mathrm{p}$.

Wolcott, S. W., 1984, Streamflow routing in the Schoharie Creek basin near North Blenheim, New York: U.S. Geological Survey Water-Resources Investigations Report 84-4053, 20 p.

Zembrzuski, T. J. Jr., and Dunn, B., 1979, Techniques for estimating magnitude and frequency of floods on rural, unregulated streams in New York State excluding Long Island: U.S. Geological Survey Water-Resources Investigations Report 79-83, 66 p. 


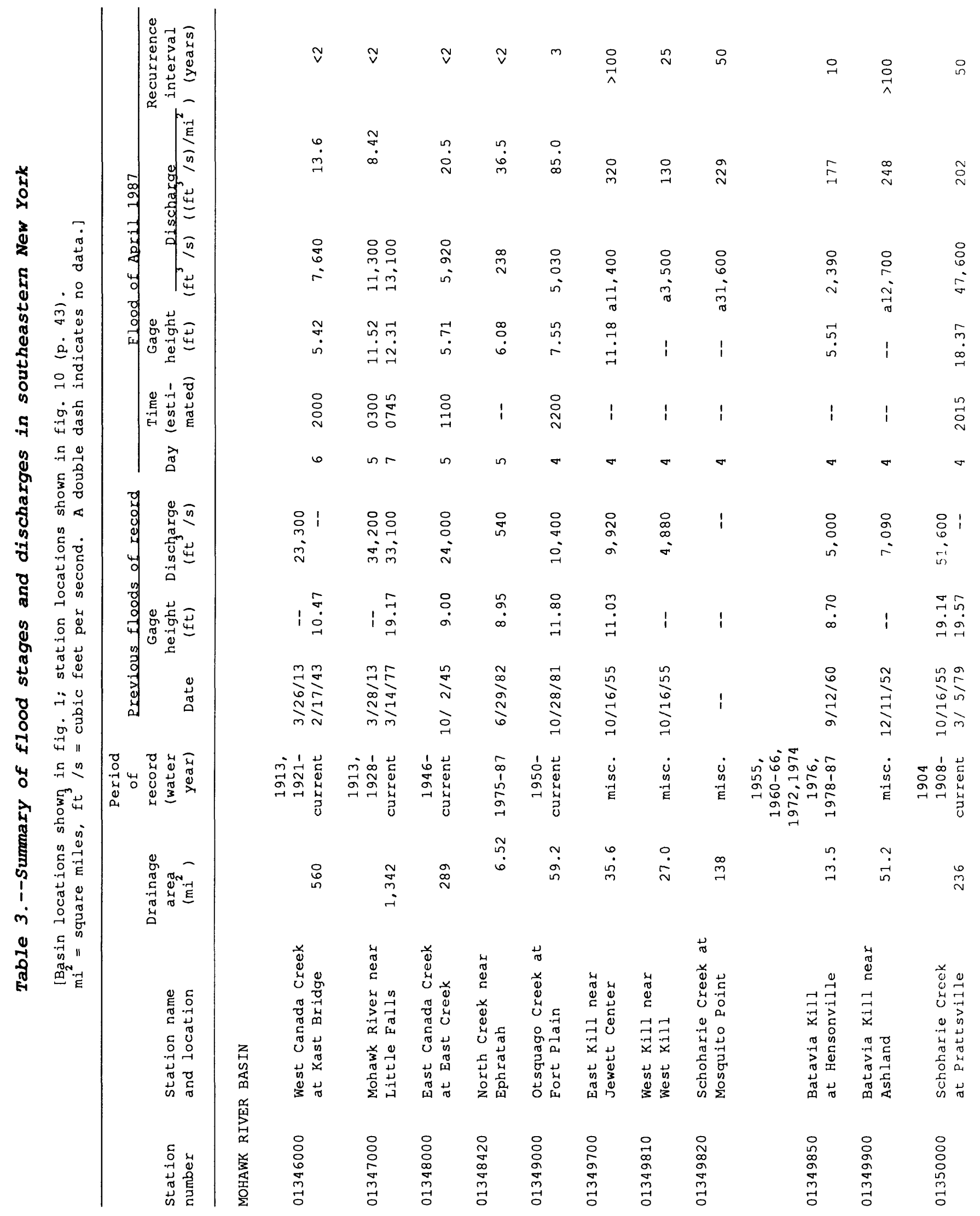




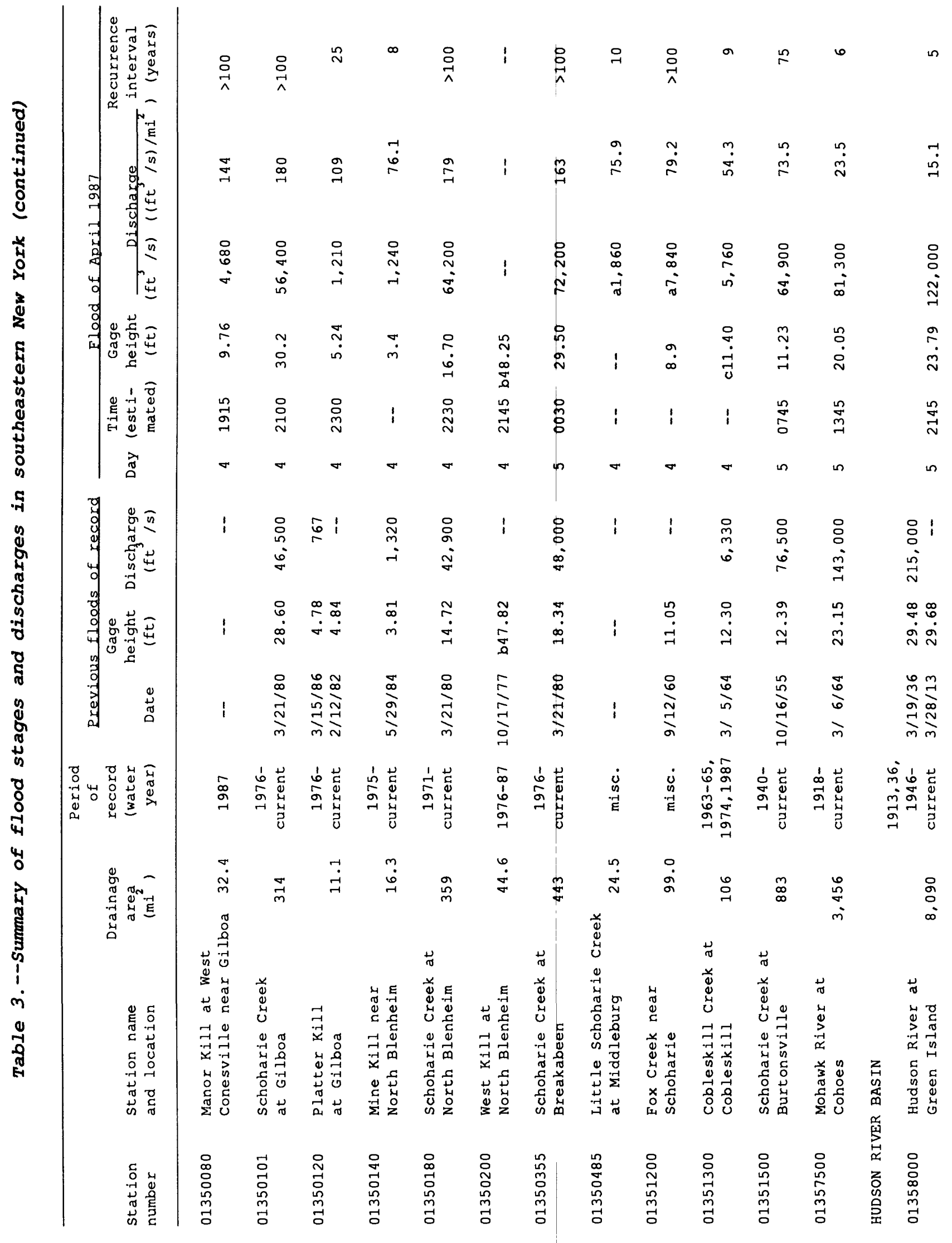




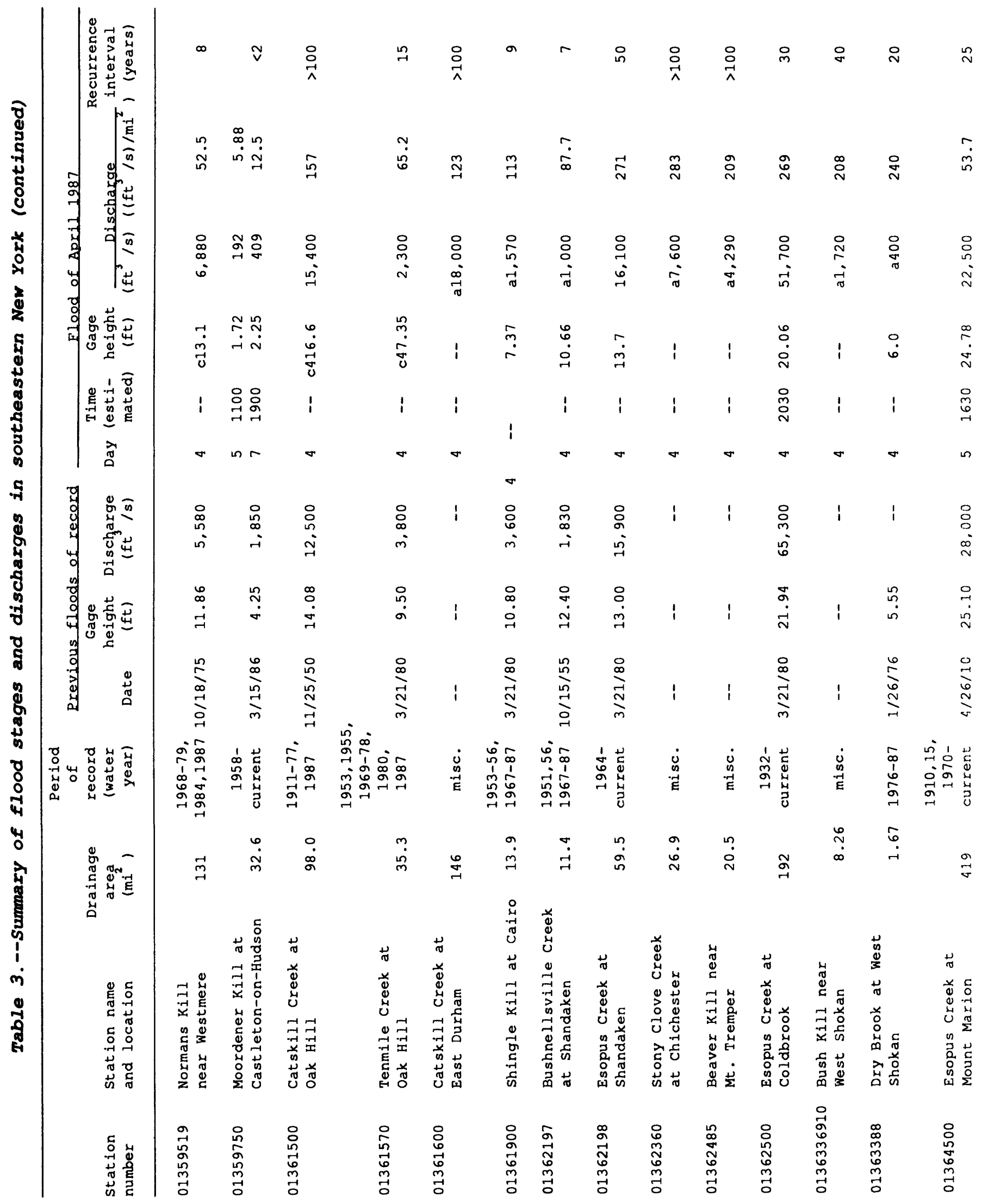




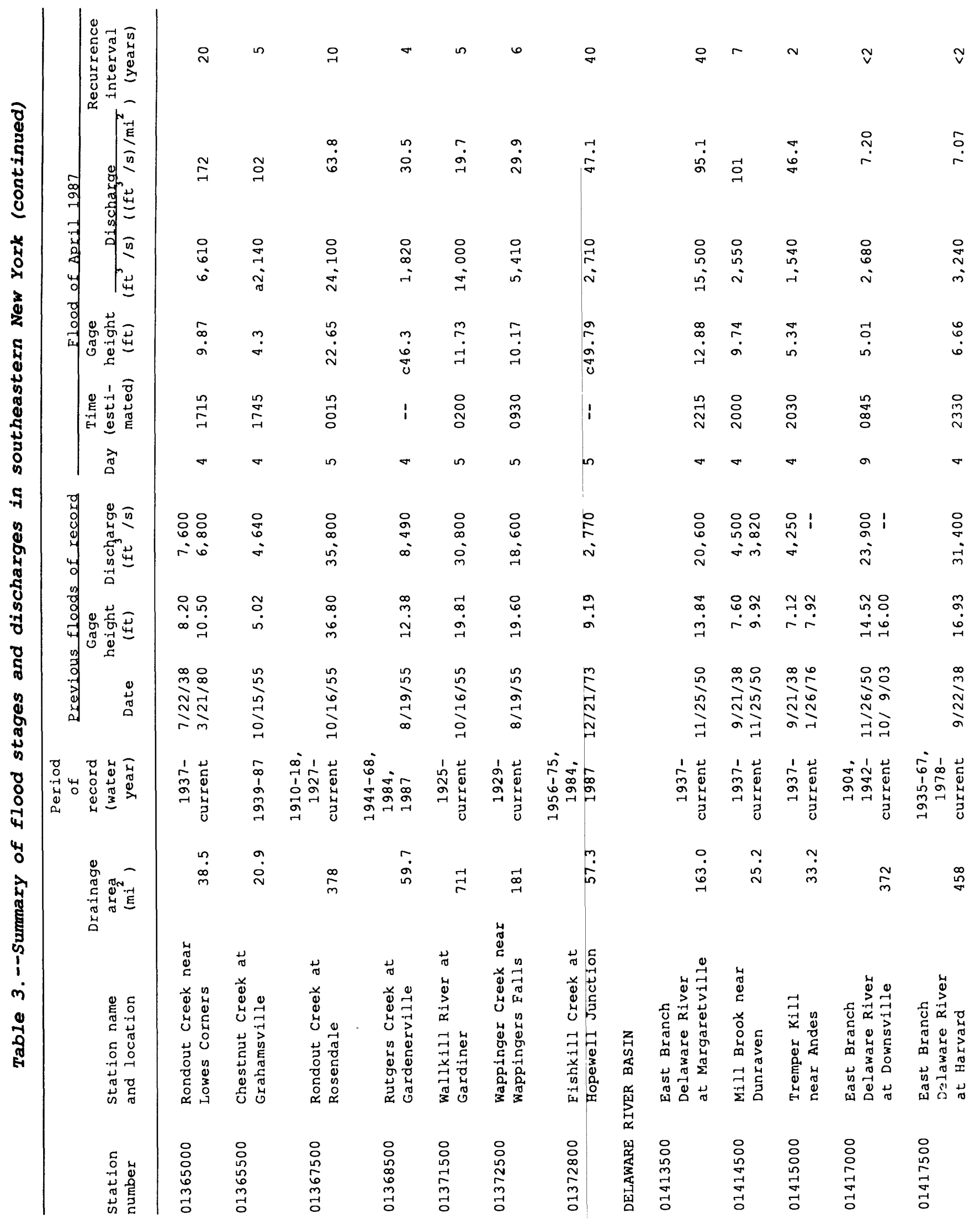




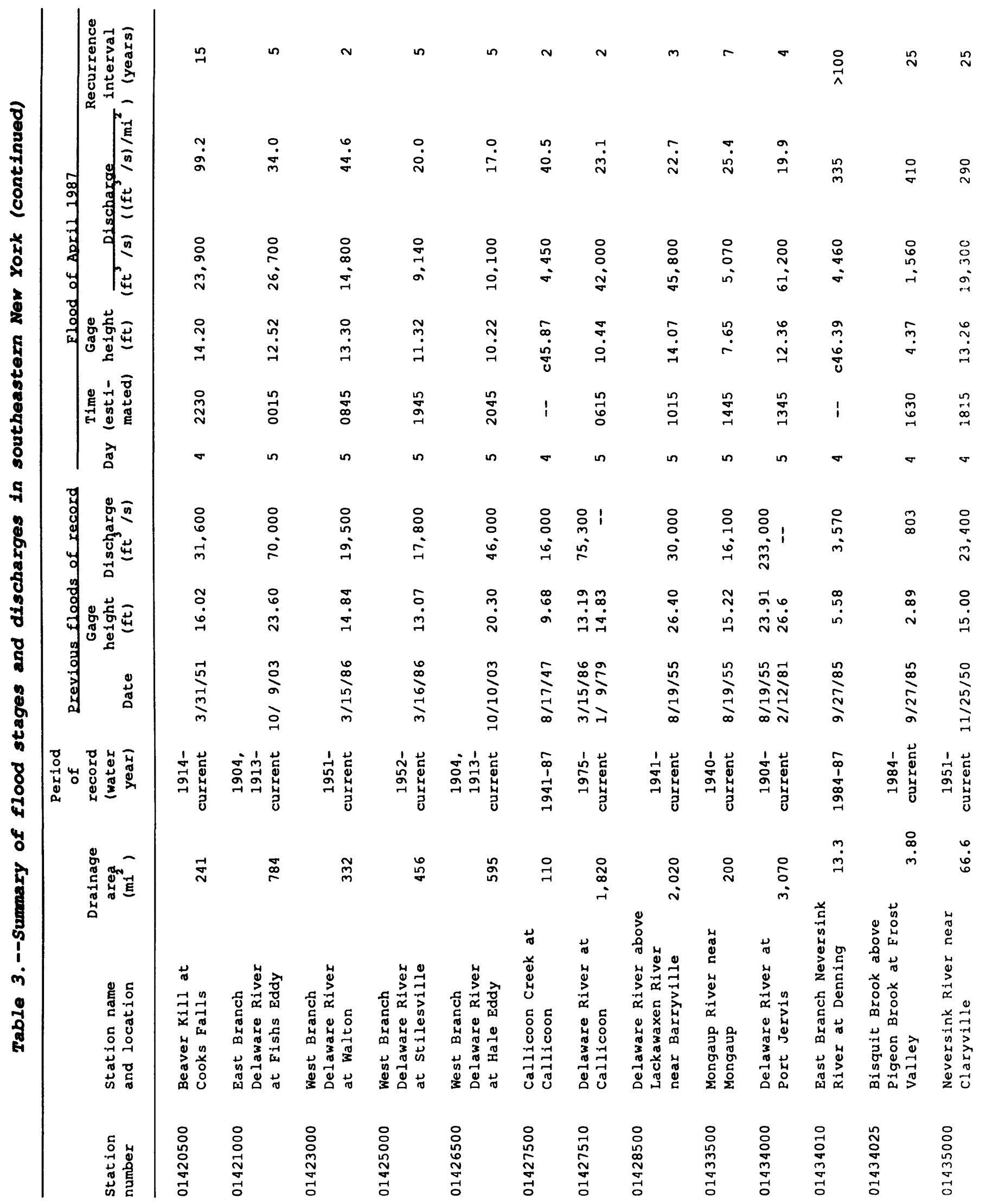

